\title{
Lüster Sırlarının Karakterizasyonuna Genel Bir Bakış
}

\author{
Aslı Asiye AĞIL, Bekir KARASU \\ Eskişehir Technical University, Engineering Faculty, Department of Materials Science and Engineering, \\ 26555, Eskişehir TÜRKIYE, \\ bkarasu@anadolu.edu.tr
}

Received/Geliș: 16.08 .2018

Accepted/Kabul: 07.11.2018

Öz: Lüster, camsı bir matris (konak) içine gömülü metal bakır ve/veya gümüş nano- taneciklerinden yapılmış bir tür metal-cam kompozittir. Metal parçacık boyutları 5-50 nm arasında değişir ve bünye üzerinde $100 \mathrm{~nm}$ ile $1 \mathrm{~mm}$ kalınlı̆̆ında bir tabaka oluşturur. Katmanların rengi ve saydamlığı, tabakadaki ışığın emilimi ve saçılımından kaynaklanmaktadır. Kullanılan pigmentler karakteristik metalik parlaklığı asla göstermezler, bunun yerine yanardöner lekeler halinde görünürler. Lüster sırlı seramikler ilk olarak MS 9. yüzyılda Abbasi Hanedanlığı Dönemi'nde, Mezopotamya'daki Samarra ve Basra gibi kentlerde İslam seramikçileri tarafindan elde edilmiş süslü seramiklerdir. İlk örnekleri Mısır'ın başkenti olan Fustat'da Fatimi Hanedanı zamanına aittir. Ardından Suriye (12-15. yy.) ve İran'da (12-17. yy.) üretilmişlerdir. Her dönem ve yere özgü olarak lüster sırlarının karakteristik stilleri de değişmektedir. Bu çalışma lüster sırlarının geçmişten günümüze yaşadığı yolculuğu özetlemektedir.

Anahtar kelimeler: Lüster, Sır, Tarihçe, Üretim, Özellik, Karakterizasyon.

\section{A General Look over the Characterisation of Lustre Glazes}

\begin{abstract}
Lustre is a kind of metal-glass composite made of glassy matrix in which metallic copper and/or silver nano-particles are embedded. The size of particles varies between $5-50 \mathrm{~nm}$ and form a layer of $100 \mathrm{~nm}-$ $1 \mathrm{~mm}$ on body. The colours and brightness of the layers are due to the light absorption and dispersion by the layer itself. The pigments used never exhibit metallic brightness, instead they appear as iridescent spots. Lustre glazes, for the first time, were patterned glazes produced by Islamic ceramists in Samarra and Basra cities of Mesopotamia during Abbasid Dynasty in 9. century AC. Its preliminary samples belong to Fustat, the capital of Egypt of Fatimid Dynasty. After, they had been produced in Syria (12-15. century AC) and Iran (12-17. century AC). Each Era and region inhibit their original characteristics. Hereby, the historical journey and general knowledge about lustre glazes are summarised.
\end{abstract}

Keywords: Lustre, Glaze, History, Production, Properties, Characterisation.

\section{Giriş}

Metaller için plazmon frekansları tipik olarak mor ötesi dalga boyundadır. Bu da metalleri renksiz ve opak kılar, ancak altın veya bakır gibi bazı metaller için sırasıyla 2,4 eV (520 nm) ve 2,1 eV (590 $\mathrm{nm})$ dalga boyları karakteristik sarı ve kırmızı renklerini verir. Metal nano-parçacıklar, genellikle tüm dalga boyları için saydamdır [1]. Genelde bir lüster tabakasında bileşimce \% 100 gümüşten \% 100 bakıra kadar değişiklik gösteren miktarlarda hem $\mathrm{Cu}$ hem de $\mathrm{Ag}$ mevcuttur [2].

İlk indirgenmiş bakır ve gümüş pigmentlerinin cam cisimlere uygulanması MS 8. ve 9. yy'lara kadar uzanmaktadır [3-4]. 1970'de Brill, bu süslemelerin camdaki alkalilerle gümüş ve bakır 
arasındaki iyonik değişim sonucu oluştuğunu ileri sürmüştür [5]. Çanak çömlekler, metal ve cam eşyalara benzeyecek biçimde renklendirilmiş ve parlaklık kazandırılmıştır.

MS 9. yüzyılda Abbasi sırları iki, üç, bazen dört parlak renk içeren, karışık desenli ve çarpıcı etkiye sahip şekildelerdi. Tipik renkler zeytin yeşili; kahverengi ve kehribar; turuncu, sarı, kırmızı ve neredeyse siyaha yakın koyu tonlardaydı. Bazen, farklı bileşimdeki metalik ve metalik olmayan parlak renkler karıştırılırdı. Bakır kırmızısı gibi kimi parlak renkler diğerlerine göre daha güçlüdür. Özellikle gümüş esaslı yeşil metalik altın parlaklık kolayca üretilmiştir [6]. Altın parıltılı lüsterlerin beğenilmesiyle MS 10. yüzyılın başlarında tek renkli zeytin yeşili altın lüsterin üretimi başlamıştır. Bazen altın metalik parlaklığ 1 veren lüsterler üretilemese de yeşil-sarı metalik lüsterlerin üretimi başarıyla sonuçlanmıştır. Bu yeni lüsterler bardaklar, kadehler, sürahiler ve kavanozların yanı sıra hayvan figürlerine de (ceylanlar, filler ve kuşlar) uygulanmaya başlanmıştır.

Sırlı çömlekler üzerine aplike edilen ilk parlak süslemeler, büyük olasılıkla MS 766-809 yıllarında Harun-al-Rashid zamanında üretilmiş olup, MS 836-883 yıllarında Samarra'daki Calips Sarayı'nda, Abbasi lüsterleri de Tunus'daki Kerouian Cami'sinde ve Cezayir'deki Hammanid Prensesi Mahkemesi'nde aynı zamanda da Mısır Fustat'daki Ahman ibn Tulun Mahkemesi'nde MS 868 yilında bulunmuştur [4, 7].

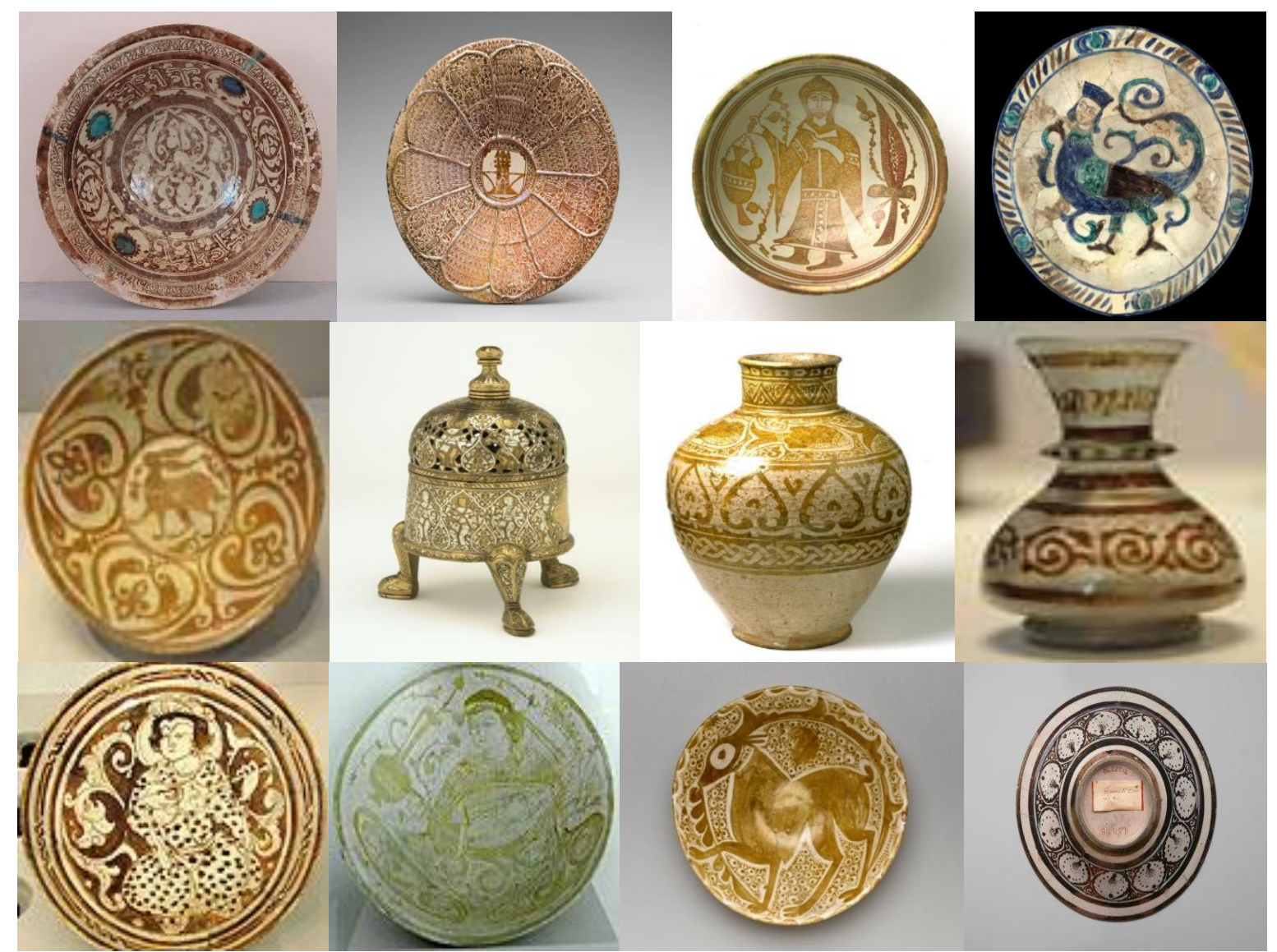

Şekil 1. İslamik (Suriye, İran, Irak, Mısır, Hindistan) lüster uygulamalarına ait örnekler [9-17].

\section{Lüster Sırlarının Üretimi}

Seramik objeler kurutulduktan sonra genellikle $900-1000{ }^{\circ} \mathrm{C}$ arasında bir ön pişirime tabi tutulup (bisküvi pişirimi) ardından sırlanarak tekrar pişirilirler. Sonrasında, seramik objeye mineral pigmentlerinden oluşan bir sır karışımı uygulanır. Ardından da indirgen atmosfer altında üçüncü bir pişirim işlemi gerçekleştirilerek obje soğutulup fırından alınır. Yıkanıp silinmeyi takiben ortaya 
harika, metalik lüsterli ürün çıkar. Bilinen neredeyse tüm lüsterler 1800'lerden önce İslamik, İspanyol ve İtalyan Lüsterleri olarak üç grupta toplanmaktadır [8]. Söz konusu lüster uygulamalarına ait fotoğraflar Şekil 1-4'te yer almaktadır.
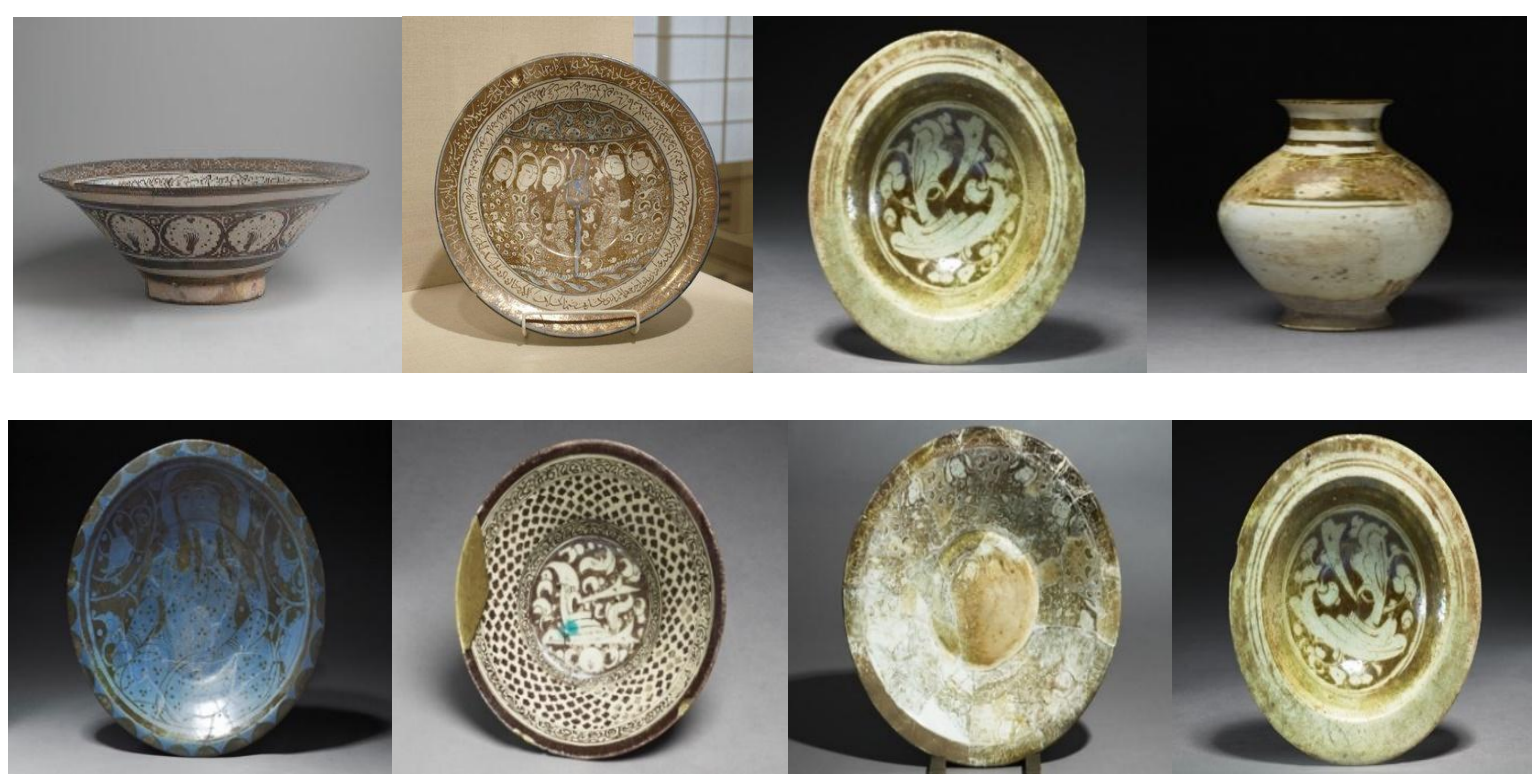

Şekil 2. İslamik (Suriye, İran, Irak, Mısır, Hindistan) lüster uygulamalarına ait örnekler [9-17].
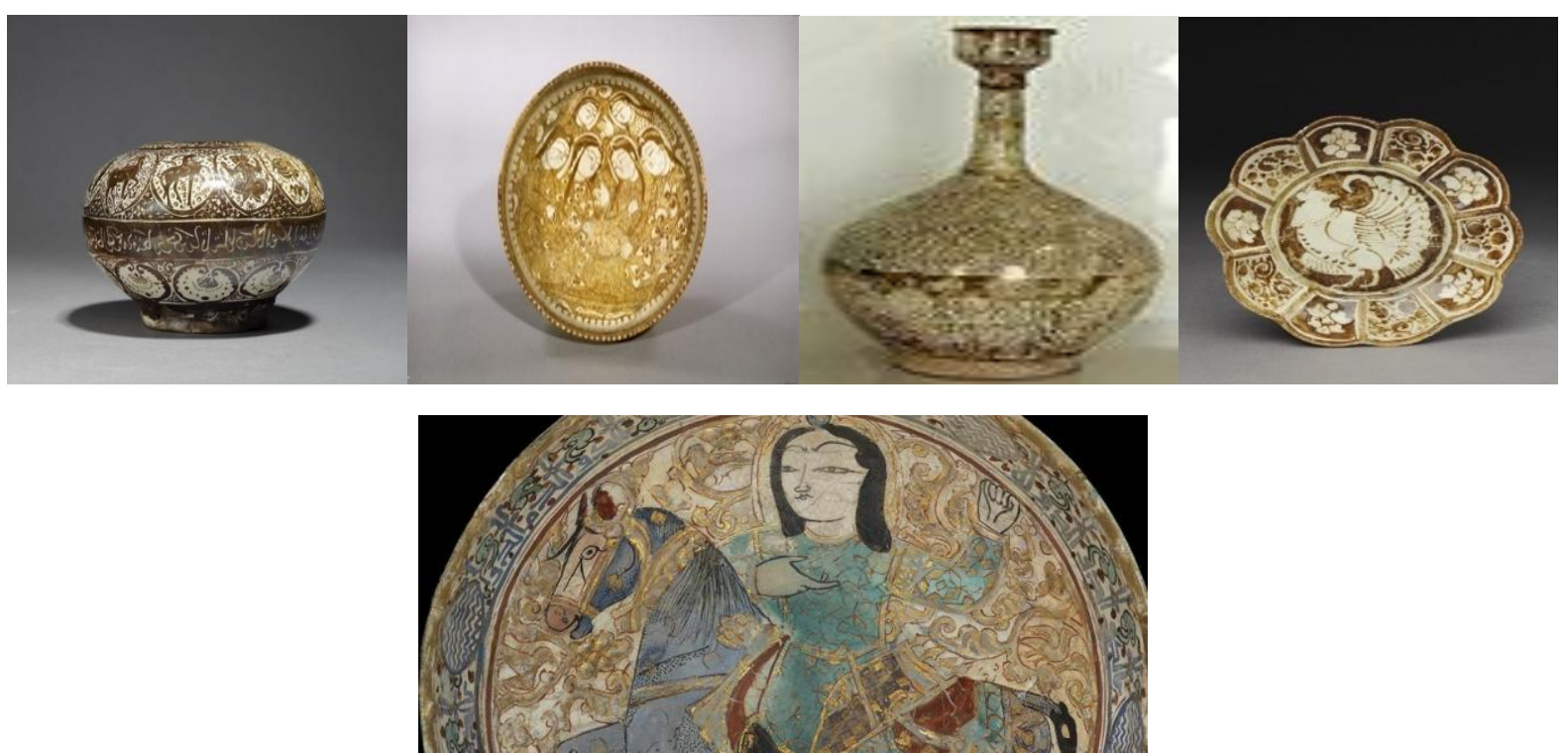

Şekil 3. İslamik (Suriye, İran, Irak, Mısır, Hindistan) lüster uygulamalarına ait örnekler [9-17].

\section{Son Dönem Çalışmaları}

Lüster, orta çă̆ sırlı seramiklerinin yüzeyine uygulanan dekoratif metalik bir film şeklinde ortaya çıkmıştır. Düşük sıcaklıkta $\left(650^{\circ} \mathrm{C}\right)$, bakır ve gümüş bileşenlerinin kontrollü indirgenmesiyle elde edilebilirler. Lüster aslında insanlar tarafından üretilen ilk tekrarlanabilir nano-yapılı ince bir metalik tabakadır. Arantegui vd. tarafından yapılan çalışmada 13. ve 16. yüzyıllar arasındaki İspanyol ve İtalyan lüster çanak çömlekleri incelenmiş [26], sır uygulanmış yüzeylerin analizleri sonucunda İspanyol ve İtalyan lüster uygulamaları arasındaki farklılıklar ortaya çıkarılmış, İspanyol sırlarının, İtalyan sırlarına göre kurşun bakımından daha zengin olduğu görülmüştür (Tablo1). 

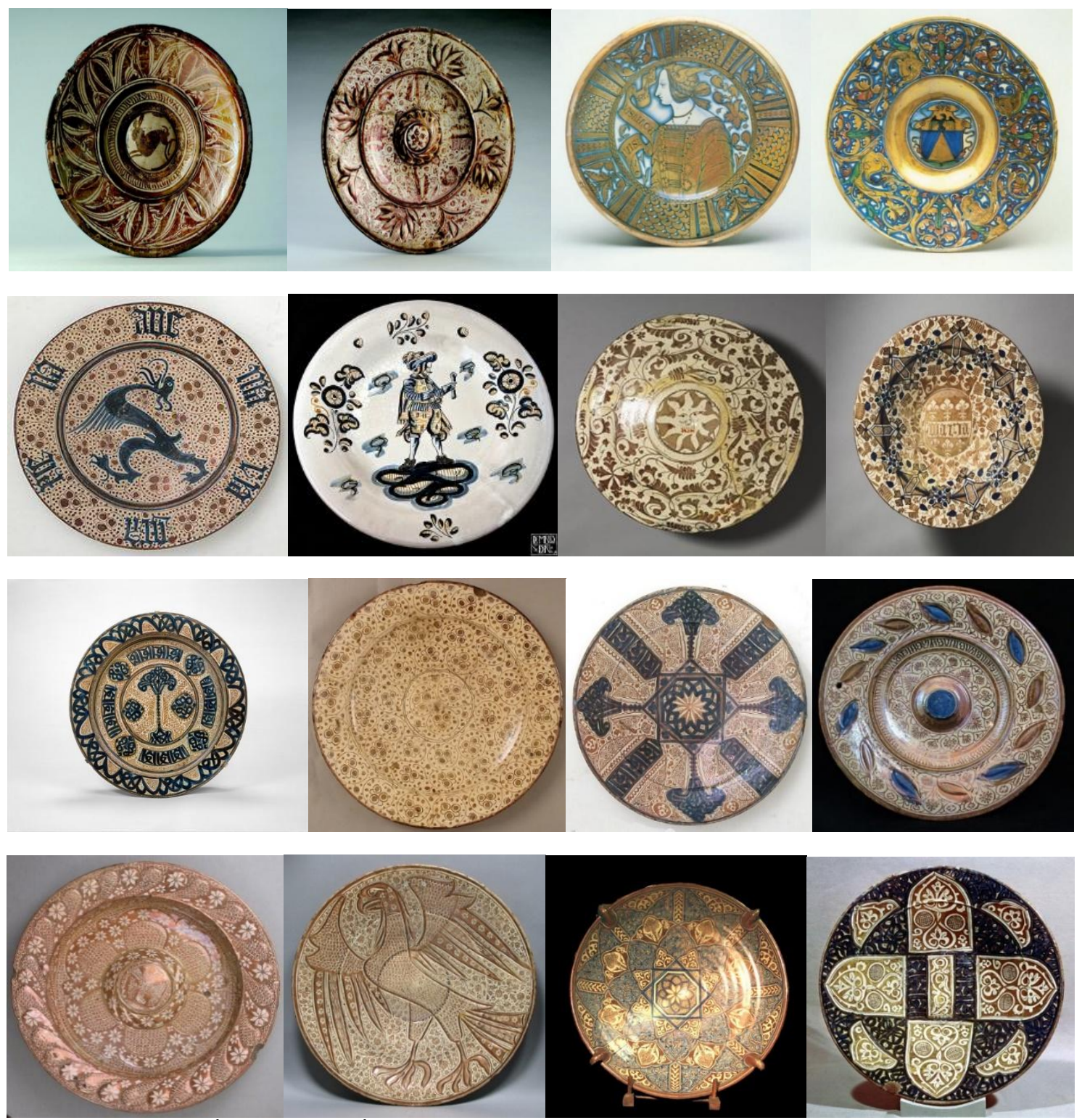

Şekil 4. İspanyol ve İtalyan lüster uygulamalarına ait örnekler [18-25].

Orta Çağ ve Rönesans Dönemi'nde İspanya ve İtalya'da üretilmiş lüster örnekleri üzerinde mikroyapısal ve kimyasal karakterizasyonlar gerçekleştirilmiştir. Lüster tabakasını oluşturan nanoboyuttaki tüm elementlerin kristal parçacıklar arasındaki mesafe, bakır ve gümüş miktarı gibi parametreler lüsterin optik özelliklerini belirlemektedir. Tarihsel ve arkeolojik bir bakış açısına göre bu sonuçlar lüsterin insanlar tarafından üretilen ilk yüksek yoğunluklu nano-küme ince filmi olduğunu ve karakteristiklerinin Hispano-Moresque ve İtalyan lüster seramiğinin ortak üretim teknolojisini doğruladığını göstermektedir.

Borgia vd., tarihi çömleklerin sırlarında metal nano-kristallerin heterojen dağılımı ile ilgili araştırmalara imza atmışlardır [27]. Çalı̧̧malarında yakın zamanda, Ortaçağ ve Rönesans çömlekçiliğinde lüster dekorasyonunun, seramik sırın camsı matris (konak) içinde dağılmış gümüş ve bakır nano-kristallerden oluştuğu gösterilmiştir. Lüster yüzeyler, metalik yansıma ve yanardönerlik gibi kendine özgü optik özellikler sergilerler.

Tablo 1. İncelenen sırların kimyasal bileşimleri [26]

\begin{tabular}{|c|c|c|c|c|c|c|c|c|c|}
\hline \multirow{2}{*}{$\begin{array}{l}\text { Sir } \\
\text { Örnekleri }\end{array}$} & \multicolumn{9}{|c|}{ 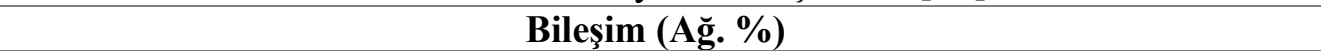 } \\
\hline & $\mathrm{SiO}_{2}$ & $\mathrm{PbO}$ & $\mathrm{Na}_{2} \mathrm{O}$ & $\mathrm{K}_{2} \mathrm{O}$ & $\mathrm{Al}_{2} \mathrm{O}_{3}$ & $\mathrm{CaO}$ & $\mathrm{MgO}$ & $\mathrm{FeO}$ & $\mathrm{SnO}_{2}$ \\
\hline
\end{tabular}




\begin{tabular}{lccccccccc} 
İspanyol & $40-45$ & $35-42$ & $0,5-1$ & $2-4,5$ & 2,3 & $1,6-2$ & 0,3 & $0,2-0,4$ & 9 \\
İtalyan & $45-65$ & $15-35$ & $1-3$ & $5-9$ & $2,5-5$ & $1,5-5$ & 0,5 & $0,5-2,5$ & $5-9$ \\
\hline
\end{tabular}

Burada, 16. yüzyıl Deruta ve Gubbio çanak çömleğine ait çeşitli parçaların sırları, pigmentleri ve parlaklıklarıyla ilgili çalışmanın bulguları sunulmuş, sır ve pigment bileşenleri tanımlanmıştır. İlgili çalışmada incelenen seramik Şekil 5'te takdim edilmiştir.

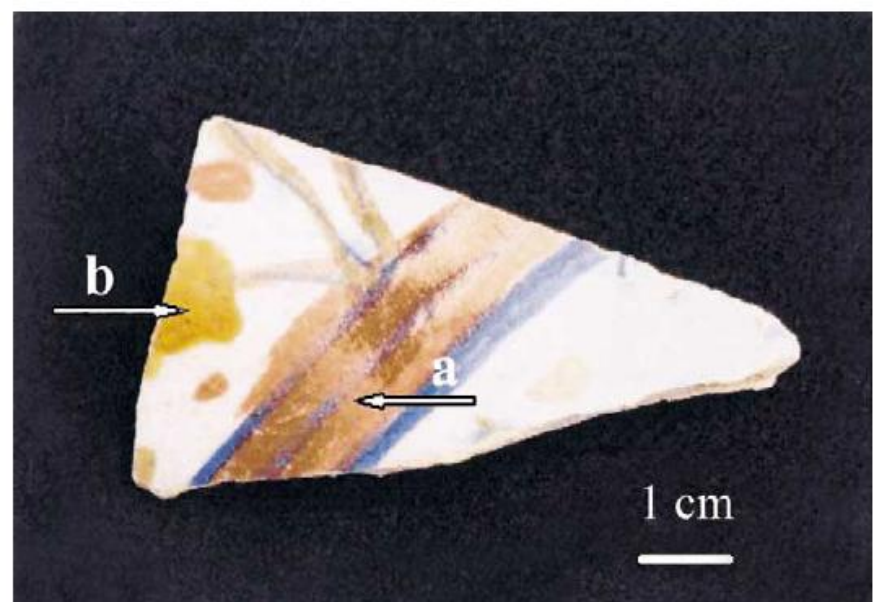

Şekil 5. Altın, gümüş ve bakır lüsterleri içeren 16. yüzyıl Gubbio seramik örneği [27].

Sırın İslamik lüster çömlekleriyle karşılaştırıldığında nispeten daha fazla miktarda alkali içerdiği belirlenmiştir. Parlaklık, gümüş ve bakır nano-kristallerin heterojen dağılımı ile karakterize edilmektedir. Gümüş nano-kristallerin bakırdan çok iyi ayrıldığı ve bakır nano-kristallerden daha büyük ortalama çapta ve küresel şekilde olduğu bulunmuştur.

Padovani vd., Rönesans lüster çömleklerinin sırlarında bakırın, nano-parçacıkların, iyonların ve yerel çevrenin etkisini incelemişlerdir [28]. Tarihsel çömlek sırlarında parlak süslemelerin camsı bir ortama yayılmış bakır ve gümüş nano-taneciklerden oluştuğu bulgusunun ardından, bakır nanoparçacıkların, bakır iyonlarının ve bunların bileşimi ve dağılımı, altın ve kırmızı renkli lüster örneklerinde incelenmiştir. Bakır iyonlarının durumu ve yerel ortamı, bakır-alkali iyon değiştirmeli silikat cam numunelerinde bulunanlara benzemektedir. $\mathrm{Bu}$, ilk adım olarak lüster oluşumuna bir bakır ve gümüş--alkali iyon değişiminin aracılık ettiği, ardından metal nano-parçacıkların çekirdeklenmesi ve büyümesinin gerçekleştiği görüşünü kuvvetle desteklemektedir. Altın ve kırmızı parlak süslemelerin mevcut olduğu iki adet Umbria Rönesans Dönemi lüster çömlek parçası üzerinde bileşimsel, yapısal ve optik ölçümler alınmıştır. Museo Regionale della Ceramica di Deruta'ya ait parçalar Şekil 6'dan izlenebilir. Ölçümler, şekilde beyaz oklarla işaretlenen kırmızı (örnek D52) ve altın (örnek D78) süslemeleri üzerinde yapılmıştır.

Elde edilen bulgulara göre altın lüsterde, elementel gümüş ve bakır ağırlıkça sırasıyla \% 20 ve 1-3 arasındadır. Metal nano-parçacıklar pratikte sadece gümüşten yapılmıştır. Kırmızı lüsterde ise, elementel bakır ağırlıkça yaklaşık \% 8 olup bakır nano-tanecikleri mevcuttur. Bununla birlikte, bakırın sadece küçük bir kısmı metalik $\left(\%\right.$ 20) geri kalanı ise $\mathrm{Cu}^{+}$formundadır. Altın ve kırmızı renkler sırasıyla gümüş ve bakır nano-parçacıklara atfedilebilir. Hem altın hem de kırmızı lüsterde, bakırın önemli ölçüde oksitlenmiş formlarda bulunması, XRF veya indüktif olarak eşleşmiş plazma atomik yayınım spektroskopisi ile gerçekleştirilen önceki denemelerin başarısızlığını ortaya çıkarmıştır. 


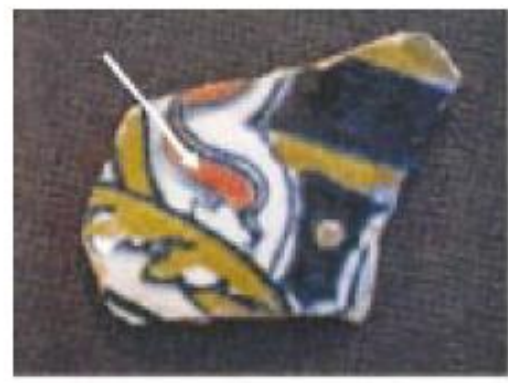

D52

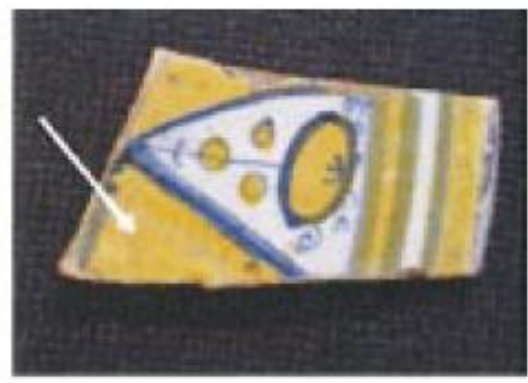

D78

Şekil 6. Deruta'dan 16. yüzyıla ait çanak çömlek örnekleri [28].

Fredrickx vd., lüster camlarındaki nano-parçacıklarını geçirimli elektron mikroskobu (TEM) ile incelemişlerdir [29]. Yüksek çözünürlüklü TEM, elektron enerji kaybı spektroskopisi ve enerji dağılım x-1şını (EDX) analizi verileri; lüster tabakasında metalik Ag ve metalik $\mathrm{Cu}$ parçacıkları olmak üzere iki çeşit nano-parçacık bulunduğunu ortaya koymuştur. Ayrıca, bu tanecikler malzeme içerisinde birbirinden belirgin bir biçimde ayrılmıştır. Yoğun üst tabaka Ag parçacıklarından ve bu üst tabakanın altında meydana gelenler ise metalik Cu'dan kaynaklanmaktadır. Nano-parçacıkların boyutlarının nüfuz etme derinliklerine göre bir derinlik profili çizilmiş, tanecik büyüklüklerinin 5$15 \mathrm{~nm}$ aralığında olduğu rapor edilmiştir. Söz konusu çalışmada kullanılan lüster katmanının genel görünüşü ve EDX analizi Şekil 7'den izlenebilir.

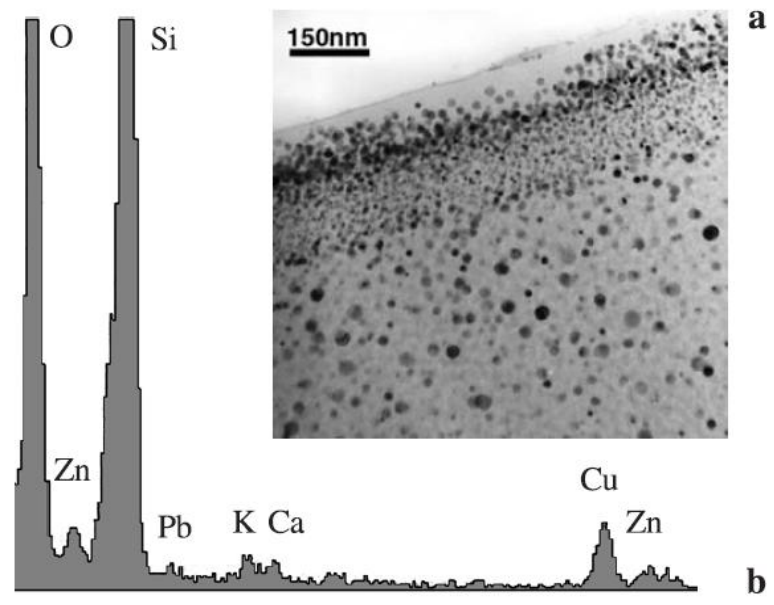

Şekil 7. Lüster katmanının genel görünüşü ve EDX analizi [29].

Lüster sırlı numuneler kesit yönelimli olarak incelenmiştir. Bu yönelim, makro, mikro ve nanoskopik katmanlı yapıyı tamamen anlamamızı sağlamaktadır. Yüzeyin hemen altında herhangi bir parçacık içermeyen cam benzeri bir tabaka görülebilir. Nano-parçacıklar maksimum 70 nm'lik bir derinlikten itibaren mevcuttur.

Pradell vd., lüster üretiminde parlak kırmızı civa sülfürün (cinnabar) etkisini araştırmışlardır [30]. Lüster süslemelerinin üretiminde parlak kırmızı civa sülfür kullanımına atıfta bulunan eski belgeler yakın zamanda arkeolojik bulgular tarafından desteklenmiştir. Ancak, lüster dekorlarının bileşimlerinde cinnabar kullanımının izine rastlanmamıştır, çünkü 500-600 ${ }^{\circ} \mathrm{C}$ 'da pişirim cinnabarın tamamen ayrışmasına ve buharlaşmasına yol açmaktadır. Bir yerinde (in-situ) $\mathrm{x}-1$ şını kırınım deneyi, lüster süslemeleri üretiminde cinnabarın rolünü açıklığa kavuşturmak için tasarlanmıştır. Sonuçlar cinnabarın bakır için indirgeyici işlev gördüğünü, bakır $\left(\mathrm{Cu}^{+}\right)$ve gümüşün $\left(\mathrm{Ag}^{+}\right)$kükürt içeren fazların oluşumunu sağladığını ve lüster üretiminde ilgili sıcaklıktaki metalik 
gümüşün kristalleşmesini önlediğini göstermiştir. Cinnabar, bakır için indirgen olup kükürt açısından zengin bir ortam sağlamakta, $500-600{ }^{\circ} \mathrm{C}$ arasında $\mathrm{Cu}^{+}$ve $\mathrm{Ag}^{+}$kükürt içeren fazların oluşumuna sebebiyet vermektedir.

Ceretti vd., eski İslam coğrafyasında, Moresque İspanya'sında ve Rönesans İtalya'sında sırlı seramiklerin dekorasyonunda nanometrik yüzey işlemenin etkilerini araştırmışlardır [31]. Lüster, sırlı seramiklerde üretilen en etkileyici yüzey dekorlarından biridir. 9. yüzyılda Arapların (Doğu Mezopotamya, Mısır ve Pers) fetihleri sırasında kurduğu atölyelerde doğmuş gibi görünmektedir. Arap çömlekçiler, bilhassa İspanya başta olmak üzere Akdeniz havzasına tüm bilgi birikimlerini yaymışlar, İtalyan Rönesans çömlekçileri de bundan faydalanmışlardır. Teknik, metalik tuzların varlığında indirgenmiş bir atmosferde sırlı seramiklerin özel pişirim işlemine dayanmaktadır. Sonuç, altından kırmızıya veya kahverengine kadar çeşitli renkler sergileyen metalik görünüme sahip bir yüzey tabakasıdır.

Pradell vd., Ortaçağ lüster süslemelerinin oluşumunda iyon değişim mekanizmasını incelemişlerdir [5]. Orta Çağ lüster seramiklerinin analizi, lüster tabakalarının oluşumunun sırın bazı alkali iyonları $\left(\mathrm{Na}^{+}\right.$ve $\left.\mathrm{K}^{+}\right)$ile pişirim esnasında lüster ham pigmentinin bakır ve gümüş katyonları arasında bir iyon değişimi içerebileceğini göstermiştir. Sunulan deneysel veriler lüsterin işlenmemiş toz halindeki lüster pigmentleri ve pişirim sırasında sırın etkileşimi yoluyla meydana getirilen "yeni" bir metal camsı kompozit tabaka olduğunu belirlemiştir. Bakır ve gümüş metal parçacıkları için tipik boyutlar yüzeye daha yakın daha büyük parçacıklar ile birlikte birkaç nanometredir. Sır içinde iki oksidasyon durumunda bakırın varlığı (metal ve $\mathrm{Cu}^{+}$) gösterilmiştir. Parçacıkların yoğunluğu ve büyüklügünün, gümüş topakların oluşumu ve sır içinde iyonik $\mathrm{Cu}^{+}$ve muhtemelen $\mathrm{Ag}^{+}$varlığının lüsterlerin optik özelliklerinde etkin parametreler olabileceği düşünülmektedir.

Metalik lüster oluşum mekanizmaları ile ilgili çalışmalar Pradell vd. tarafından başarıyla gerçekleştirilmiştir [32]. Farklı çalışmalar lüsterlerin bakır ve/veya gümüş içeren pigmentlerin sırla tepkimesinden elde edilen bir metal-cam nano-kompozit olduğunu göstermiştir. Bu metal benzeri tabakaların ortaya çıkış mekanizmaları Ortaçağ lüsterinin laboratuvarda yeniden üretilip araştırılmasıyla belirlenmeye çalışılmıştır. Sırın ağırlıkça \% cinsinden kimyasal bileşimi, seçilen camlar ve lüsterin yeniden üretimi için 1sıl yollar Tablo2'de sunulmuştur.

Paterna'da Hecpano-Moresque atölyesinde MS 13. yy'dan kalma Ortaçağ tariflerinin bulunmasının ardından bakır ve gümüş lüster katmanlarının laboratuvar ortamında yeniden üretimi sağlanmıştır. Farklı sır bileşimleri, 1sıl işlemler ve atmosferler denenmiştir. Oksitleyici veya nötr atmosferlerdeki pişirim alkaliler $\left(\mathrm{Na}^{+}\right.$ve/veya $\left.\mathrm{K}^{+}\right)$ile $\mathrm{Cu}^{+}$ve $\mathrm{Ag}^{+}$arasında bir iyonik değişime yol açmıştır. İyonik değişim sonrası indirgen bir atmosferin kullanılması da $\mathrm{Cu}^{+}$ve $\mathrm{Ag}^{+}$nın metalik hallerine redüklenmesine neden olmuştur. $\mathrm{Bu}$ indirgeme aşamasında nano-kristal metalik bakır ve metalik gümüş oluşmaktadır. Nano-kristallerin tipik boyutları bakır için 15-20 nm, gümüş içinse 5-20 nm'dir.

Rio vd. Sevilla'daki 15. yüzyıldan kalma lüster kaplı seramik metalik nano-parçacıkları PIXE ve RBS ile incelemişlerdir [33]. Triana'da (Sevilla) bir atölyede bulunan lüster seramikleri lüster etkisine yol açan metalik parçacık tabakaları dahil olmak üzere sırların bileşimini belirlemek üzere analiz edilmiştir. 
Tablo 2. Sırın ağırlıkça \% cinsinden kimyasal bileşimi ve seçilen camlar ile yeniden lüster üretimi için 1sil yollar [32]

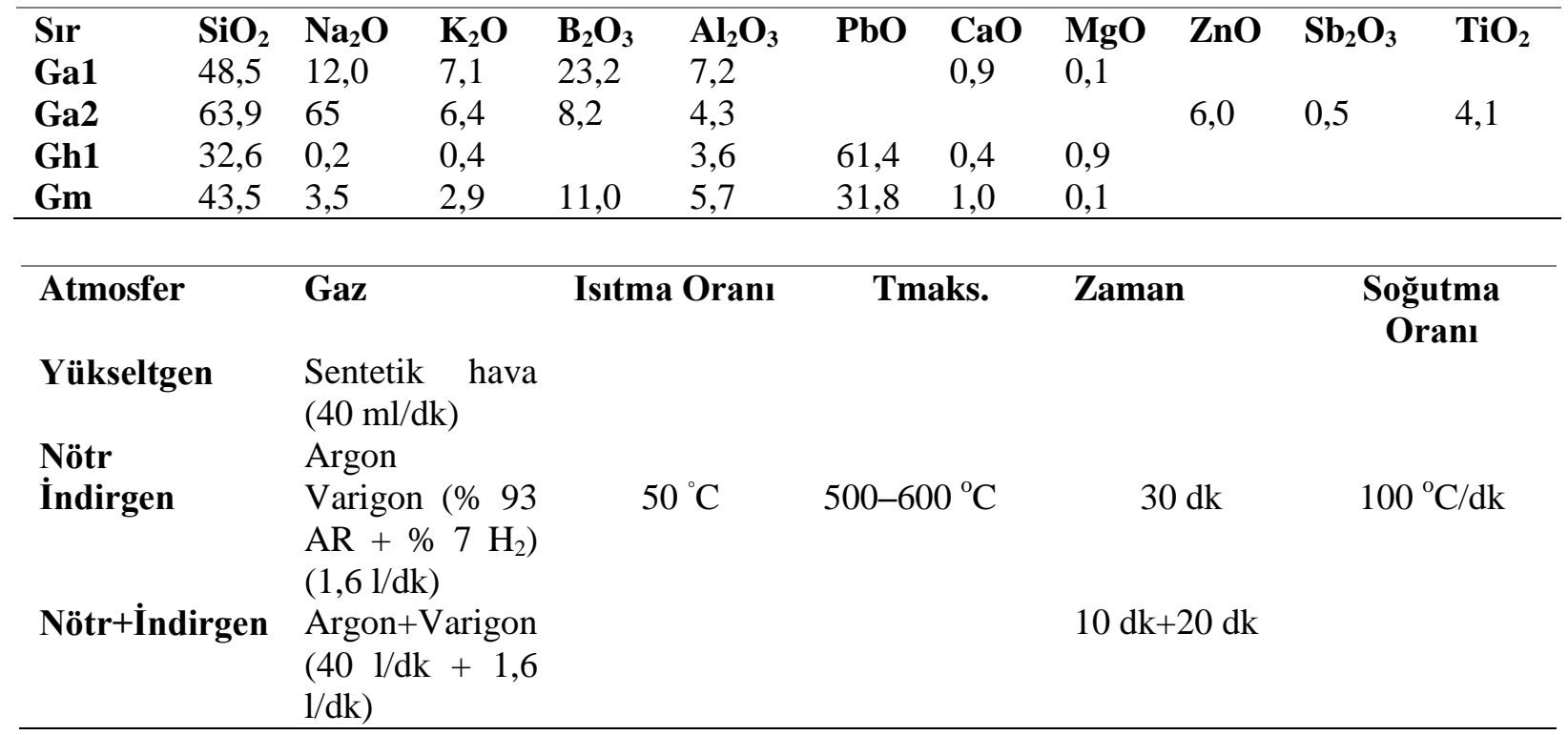

$\mathrm{Bu}$ çalışmada 17. yüzyıldan önce inşa edilen küçük bir firına bağlanan yaşam alanlarının kalıntılarının yanına atılan malzemeler içinde çok sayıda parça bulunmuştur; örnekler Şekil 8'de gösterilmiştir.

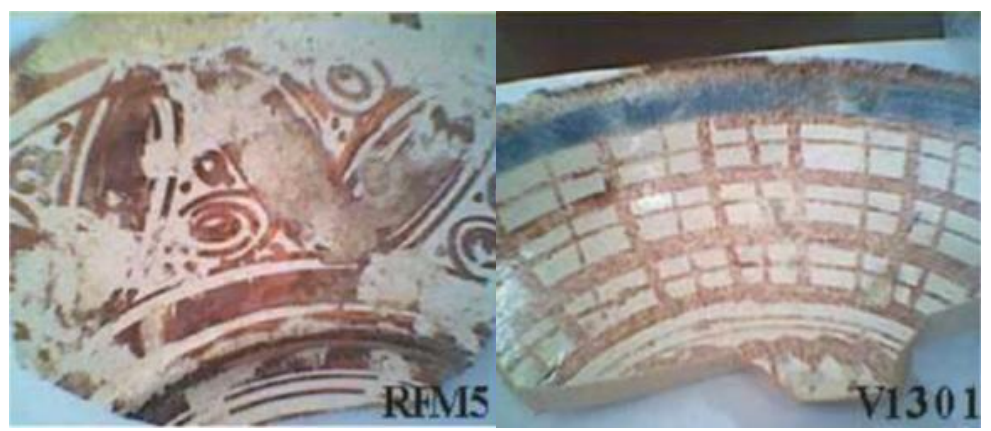

Şekil 8. Lüster seramik parça örnekleri [33].

Dış 1şın RBS, lüster eşyalarında bulunan nano-taneciklerin alt yüzey tabakalarının özelliklerinin çoğunu belirleyen en iyi tekniktir. Antik lüsterin araştırılmasında tahribatsız analiz kapasitesi nedeniyle IBA'dan faydalanılmaktadır.

Roque vd., lüsterdeki bakır ve gümüş nano-kristal sırların geliştirilmesi ve optik özellikleri ile ilgili araştırmalara imza atmışlardır [34]. MS 9. yüzyılın başlarında Irak'ın eski çömlekçileri, kil ile bazı bakır oksitleri ve gümüş tuzlarını firınladıktan sonra demir oksitlerin ve seramik sır üzerine uygulanan bazı kükürt bileşiklerinin kırmızımsıdan sarımsıya kadar geniş renk yelpazesiyle güzel bir katman oluşturduğunu keşfettiler. Yeşilimsi ve hatta bazılarının karakteristik metalik bakır veya morumsu parlaklığı vardır. Katmanların modern çalışmaları bunların bir cam konak içine gömülü nano-kristal bakır ve gümüş tarafından oluşturulduğunu göstermiştir. Şekil 9'da bu çalışmada kullanılan lüster yüzey süslemeleri ve sır kesitlerinden optik mikroskop (OM) görüntüleri verilmiştir. 
Tablo 3.a Sırların ve bünyelerin PIXE bileşimleri [33]

\begin{tabular}{|c|c|c|c|c|c|c|c|c|c|c|}
\hline & $\mathrm{Na}_{2} \mathrm{O}$ & MgO & $\mathbf{A l}_{2} \mathbf{O}_{3}$ & $\mathrm{SiO}_{2}$ & $\mathrm{P}_{2} \mathrm{O}_{5}$ & $\mathrm{SO}_{3}$ & $\mathrm{Cl}$ & $\mathrm{K}_{2} \mathrm{O}$ & $\mathrm{CaO}$ & PbO \\
\hline RFM 3 Beyaz Sir & 1,2 & 0,4 & 2,5 & 50 & & 0,4 & 0,3 & 4,7 & 2,6 & 31 \\
\hline RFM 3 Bünye & 1 & 3,2 & 14 & 50 & 0,6 & 0,4 & 0,06 & 2 & 22 & 0,3 \\
\hline RFM 5 Beyaz Sir & 1 & 1,4 & 2,8 & 49 & 3 & 2 & 1 & 4,2 & 3,2 & 25 \\
\hline RFM 5 Bünye & 1 & 3,3 & 13 & 52 & & 0,25 & 0,05 & 1 & 24 & 0,6 \\
\hline RFM 8 Mavi Sur & 0,4 & 0,3 & 1,6 & 46 & 1 & & 0,4 & 1,9 & 2,3 & 38 \\
\hline RFM 8 Beyaz Sir & 0,3 & 0,3 & 5,7 & 44 & & & & 1 & 3,5 & 36 \\
\hline RFM 8 Lüster/Beyaz Sır & 0,6 & 0,3 & 2,2 & 40 & & 1 & 1 & 1,7 & 2 & 43 \\
\hline RFM 12 Beyaz Sir & 1,1 & 0,4 & 2 & 53 & & & & 5 & 2,6 & 28 \\
\hline RFM 13 Beyaz Sir & 0,7 & 0,4 & 2,3 & 46 & & & 0,5 & 4 & 3 & 35 \\
\hline V 1300 Beyaz Sır & 0,3 & 0,4 & 2,3 & 56 & & & 0,2 & 6,2 & 2 & 25 \\
\hline V 1301 Beyaz Sir & 1,2 & 0,5 & 2,5 & 53 & & 2 & 0,5 & 6,8 & 2,8 & 22 \\
\hline V 1301 Mavi Sir & 1,7 & 0,5 & 2,5 & 53 & & & 0,4 & 6,5 & 4,2 & 21 \\
\hline
\end{tabular}

Tablo 3.b. Sırların ve bünyelerin PIXE bileşimleri [33]

\begin{tabular}{|c|c|c|c|c|c|c|c|c|c|c|c|}
\hline & $\mathrm{TiO}_{2}$ & $\begin{array}{c}\text { Mn } \\
\text { O }\end{array}$ & $\mathrm{Fe}_{2} \mathrm{O}_{3}$ & $\mathrm{CoO}$ & $\mathrm{NiO}$ & $\mathrm{CuO}$ & $\mathrm{ZnO}$ & $\mathrm{As}_{2} \mathrm{O}_{3}$ & $\mathrm{Ag}_{2} \mathbf{O}$ & $\mathrm{SnO}_{2}$ & $\mathrm{Sb}_{2} \mathrm{O}_{5}$ \\
\hline RFM 3 Beyaz Sir & 0,1 & 0,04 & 0,7 & & 0,01 & 0,06 & 0,02 & & & 6,4 & \\
\hline RFM 3 Bünye & 0,9 & 0,1 & 5,5 & & & 0,01 & 0,01 & & & & \\
\hline RFM 5 Beyaz Sir & 0,2 & 0,02 & 0,42 & & 0,01 & 0,12 & $(60)$ & & & 6,5 & \\
\hline RFM 5 Bünye & 0,75 & 0,07 & 5,3 & & $(50)$ & 0,03 & (90) & & & & \\
\hline RFM 8 Mavi Sır & 0,1 & 0,03 & 0,5 & 0,17 & 0,06 & 0,24 & $(100)$ & 0,07 & & 7,4 & 0,1 \\
\hline RFM 8 Beyaz Sir & 0,1 & 0,04 & 0,6 & & 0,01 & 0,26 & $(80)$ & 0,04 & $(150)$ & 8,2 & 0,06 \\
\hline RFM 8 Lüster/Beyaz sır & 0,1 & 0,04 & 0,5 & & 0,01 & 0,7 & (60) & 0,06 & 0,12 & 7,8 & 0,06 \\
\hline RFM 12 Beyaz Sir & 0,1 & 0,03 & 0,5 & & 0,01 & 0,06 & 0,02 & & & 7,8 & \\
\hline RFM 13 Beyaz Sir & 0,1 & 0,04 & 0,7 & & 0,01 & 0,06 & & & & 7,1 & \\
\hline V 1300 Beyaz Sir & 0,06 & 0,02 & 0,4 & & 0,01 & 0,04 & 0,01 & & & 6,7 & \\
\hline V 1301 Beyaz Sir & 0,06 & 0,02 & 0,22 & & 0,01 & 0,05 & 1,2 & & & 6,9 & \\
\hline V 1301 Mavi Sır & 0,05 & 0,04 & 0,6 & 0,6 & 0,1 & 0,08 & 0,2 & & & 8,8 & \\
\hline
\end{tabular}

Lüster nano-yapısının kristal boyutu derinliğinin bir fonksiyonu olduğu gösterilmektedir. Bu da yüzeye uygulanan ham pigmentten $\mathrm{Cu}^{+}$ve $\mathrm{Ag}^{+}$iyonlarının $\mathrm{Na}^{+}$ve $\mathrm{K}^{+}$ile yer değişimini ve ardından cam konak içindeki metalik bakır nano-kristallerin ortaya çıktığını önermektedir.
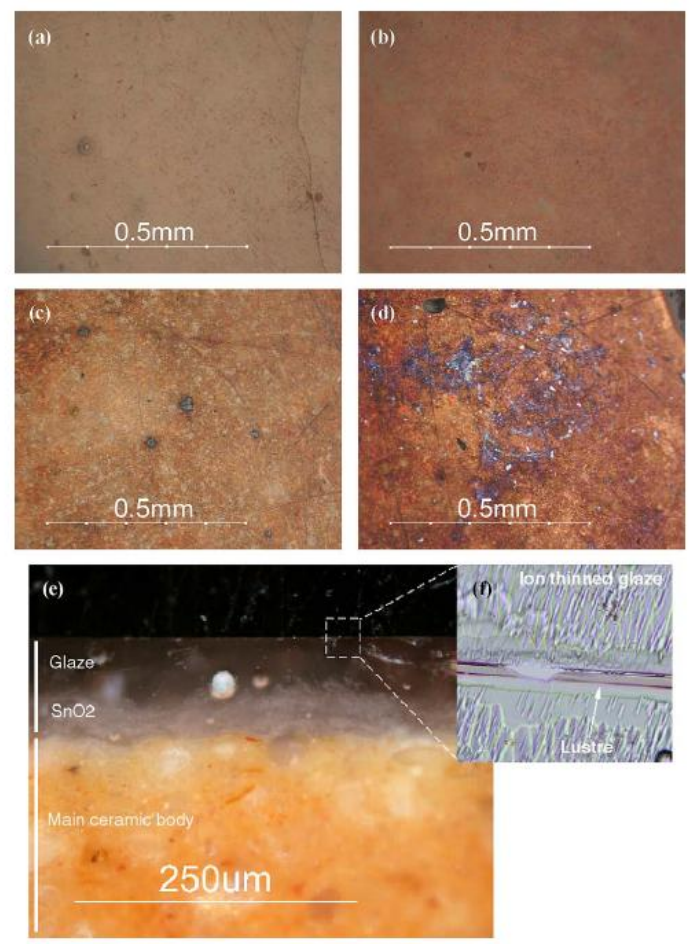

Şekil 9. Lüster yüzey süslemeleri ve sır kesitlerinden optik mikroskop (OM) görüntüleri [34]. 
Lüster oluşurken, $\mathrm{Cu}$ nano-parçacıkların kütle merkezi, nano-taneciklerin kabalaşmasından kaynaklanan ve parçacık mesafelerinin azaltılmasına yol açan küçük nano-kristallerin kaybolmasıyla birlikte yüzeye doğru kayma eğilimindedir. Sonuçta, bakır nano-parçacıklar arasındaki dipol plazmon birleşmesi görünür. Ayrıca, sır yüzeyindeki renk, saçılan veya yansıyan 1şıktan hareketle belirlendiğinde farklılık gösterir. Gümüş renginde yansıyan nano-kristaller kırmızımsı bakır yayınımıyla birleştiğinde morumsu parlaklık veren karakteristik mavi bir yansımaya yol açarlar.

Ortaçağ lüster renkleri ve parıltılarının üretilmesindeki anahtar parametreler Molera vd. tarafından belirlenmiştir [35]. Farklı renk ve yansıtıcılı lüsterler Ortaçağ tarifleri kullanılarak bir laboratuvarda kontrollü koşullar altında elde edilmiştir. Pigment tariflerinin sır bileşimleri, 1sıl işlemler, atmosferlerin son hali ve oluşan $\mathrm{Ag} / \mathrm{Cu}$ nano-kompozit tabakasının özellikleri üzerindeki etkisi incelenmiştir. Tablo4 araştırılan cam ve sırların ağırlıkça \% kimyasal bileşimlerini göstermektedir.

Tablo 4. Cam ve sırların ağırlıkça \% bileşimi [35]

\begin{tabular}{|c|c|c|c|c|c|c|c|c|c|c|c|}
\hline & $\mathrm{SiO}_{2}$ & $\mathrm{Na}_{2} \mathrm{O}$ & $\mathrm{K}_{2} \mathrm{O}$ & $\mathbf{B}_{2} \mathbf{O}_{3}$ & $\mathrm{Al}_{2} \mathrm{O}_{3}$ & $\mathrm{PbO}$ & $\mathrm{CaO}$ & MgO & $\mathrm{ZnO}$ & $\mathrm{Sb}_{2} \mathrm{O}_{3}$ & $\mathrm{TiO}_{2}$ \\
\hline Cam-a & 63,9 & 6,5 & 6,4 & 8,2 & 4,3 & & & & 6,0 & 0,5 & 4,1 \\
\hline Sir-a & 48,5 & 12,0 & 7,1 & 23,3 & 7,2 & & 0,9 & 0,1 & & & \\
\hline Sir-hl & 32,6 & 0,2 & 0,4 & & 3,6 & 61,4 & 0,4 & 0,9 & & & \\
\hline Sir-m & 43,5 & 3,5 & 2,9 & 11,0 & 5,7 & 31,8 & 1,0 & 0,1 & & & \\
\hline
\end{tabular}

Tablo 5. Yeniden üretilen lüsterlerin 1sıl aşamaları [35]

\begin{tabular}{|c|c|c|c|c|c|}
\hline Atmosfer & Gaz & $\begin{array}{c}\text { Isitma Hizı } \\
\left({ }^{\circ} \mathrm{C} / \mathbf{d k}\right)\end{array}$ & $\mathrm{T}_{\text {maksimum }}\left({ }^{0} \mathrm{C}\right)$ & Zaman (dk) & $\begin{array}{c}\text { Soğutma Hizı } \\
\left({ }^{\circ} \mathrm{C} / \mathrm{dk}\right)\end{array}$ \\
\hline Oksitlenme & $\begin{array}{c}\text { Sentetik hava (40 } \\
\mathrm{mL} / \mathrm{dk})\end{array}$ & 50 & 550 & 30 & 100 \\
\hline Nötr & $\begin{array}{c}\text { Argon }(40 \\
\mathrm{mL} / \mathrm{dk})\end{array}$ & 50 & 550 & 30 & 100 \\
\hline İndirgeyici & $\begin{array}{c}\text { Varigon }(\% 95 \mathrm{Ar} \\
\left.+\% 5 \mathrm{H}_{2}\right)(1,6 \\
\mathrm{mL} / \mathrm{dk})\end{array}$ & 50 & 550 & 30 & 100 \\
\hline $\begin{array}{l}\text { Nötr+ } \\
\text { İndirgeyici }\end{array}$ & $\begin{array}{c}\text { Argon }+ \text { Varigon } \\
(40 \mathrm{~mL} / \mathrm{dk}+1,6 \\
\mathrm{mL} / \mathrm{dk})\end{array}$ & 50 & $\begin{array}{c}450-600 \\
550\end{array}$ & $\begin{array}{c}10+5 \\
10+20\end{array}$ & \\
\hline
\end{tabular}

Lüster dekorasyonları başarılı bir şekilde yeniden üretilmiş ve orta parlaklıkta gözlenen farklı renkler ile metalik yansımalar/parıltılarla sonuçlanan üretim parametreleri tanımlanmış, lüster tabakası oluşumunda yer alan bazı mekanizmalar açığa kavuşturulmuştur. $550{ }^{\circ} \mathrm{C}^{\prime}$ lik pişirim sıcaklığı, camlardaki pigmentlerde ve alkalilerdeki kükürdün varlığı, lüster katmanlarının oluşumuyla sonuçlanan anahtar parametrelerdir. Lüsterle gösterilen renk ve metalimsi parlaklık tabakada bulunan nano-parçacıkların yoğunluğu ile doğrudan bağlantılıdır. Özellikle, kurşunlu sırlar için metal benzeri yansıma elde edilirken, aynı durum alkali sırlar için geçerli olmamış, sonuçlar İslamik lüsterlerin arkeolojik bulguları ile mükemmel bir uyum sağlamıştır.

Lüsterlerin nano-yapısı, kimyasal bileşimi ve 1sıl işlem koşulları Roque vd. tarafindan araştırılmıştır [36]. İspanya Paterna'da bulunan Olleries Xiques atölyesinden 13. yüzyıla ait lüster seramikleri, kimyasal bileşimleri ve nano-yapıları, renkleri ve parlaklıkları ile birleştirilerek incelenmiştir. Parlaklıkta gözlenen mavimsi yanardönerlik kimyasal bileşimle tamamen açılanamamış, metalik gümüş nano-parçacık 1şık saçınımı olası bir açıklama şeklinde önerilmiştir. Örneklerin rengi, parlaklığı, bakır ve gümüş oranı Tablo6'dan takip edilebilir.

Olleries Xiques'te lüster rengine ve kimyasal bileşime göre iki çeşit nano-yapı bulunmaktadır; gümüş metal-cam nano-kompozit ile oluşturulan sarımsı parlaklık ve bakır oksit nano-parçacıklar ile metalik bakır nano-parçacıkların oluşturduğu kırmızımsı lüster dekorasyonu. Bu oksitlenmiş 
kabuk, metalik bakır nano-parçacıklar arasındaki SPR dipol etkileşimini engellememekte ve bakır oksit ile birlikte lüster süslemeleri metalik bakır parlaklığı sergilemektedir.

Pradell vd., lüsterde metalik ve metalik olmayan parlaklığı elastik iyon geri saç1lım çalışması ile incelemişlerdir [38]. Nano-parçacıklar, $\mathrm{Cu}^{+}, \mathrm{Ag}^{+}$ve camsı konakla alkali iyonları arasında gerçekleşen iyon değişimi ve indirgen atmosferde boyutlarının büyütülmesi sonucu üretilir. Lüsterin en çarpıcı özelliği, ışığı sürekli bir metal tabaka gibi yansıtma kabiliyetidir ve beklenmedik biçimde tek bir üretim parametresiyle bağlantılı olduğu bulunmuştur. İncelenen lüster katmanlarının ana özellikleri Şekil 10'dan takip edilebilir. Sonuçlar, yüksek kurşunlu sırın üzerinde üretilen lüster tabakası tarafından sergilenen metal benzeri yansıtıcılığın katmandaki yüksek yoğunluklu parçacıklarla ve daha büyük nano-parçacık büyüklüğüyle ilintili olduğunu göstermektedir. Kurşunsuz sırların lüster katmanlarında ise düşük parçacık yoğunluğu ve nano-parçacık büyüklüğü etkilidir. Kurşun açısından zengin sırların kullanımı, metal benzeri parlatıcı lüsterlerin üretimi için ilgili teknolojik parametrelerden biri gibi görünmektedir. Bu, erken dönemdeki İslami lüsterlerin araştırması ile de uyumludur [12-13]. Verilere göre, 9. ve 10. yüzyıllardaki lüster teknolojisinin evrimi; kurşunun sır formülasyonuna girmesi ile doğrudan ilişkilidir. Misır, Suriye ve İran'da ki ilk İslami lüsterler Pradell vd. tarafından araştırılmıştır [37]. MS 10. yüzyılın son çeyreğinden MS 13. yüzyılın ikinci yarısına kadar Mısır, Suriye ve İran'dan gelen lüsterli seramikler seçilmiştir.

\begin{tabular}{|c|c|c|c|}
\hline Numune No & $\mathbf{J 3 2}$ & J6 & J65 \\
\hline Cam tipi & Cam-a & Sir-a & Sir-m \\
\hline Cam yoğunluğu $\left(\mathrm{g} / \mathrm{cm}^{3}\right)$ & 2,42 & 2,32 & 3,01 \\
\hline Camdaki kütlece $\% \mathrm{PbO}$ & 0 & 0,4 & 32 \\
\hline $\begin{array}{l}\text { Ortalama \& standart } \\
\text { sapma (at \% Cu})^{2}\end{array}$ & $3,4(1,4)$ & $2,6(1,2)$ & $1,8(1,2)$ \\
\hline Maksimum (at \% Cu$)^{2}$ & 4,8 & 4,3 & 4,0 \\
\hline $\begin{array}{l}\text { Nano parçacık boyutu } \\
(\mathrm{nm})^{3}\end{array}$ & $6,4(0,3)$ & $12,5(0,3)$ & $39,0(3,1)$ \\
\hline
\end{tabular}

Şekil 10. İncelenen lüster katmanlarının ana özelliklerinin özeti [36].

Çalışmayla, incelenen üretim merkezleri arasında tarihsel dönem boyunca parlaklığın yapısı ve kimyası üzerine yoğunlaşılmış ve bir takım anlamlı benzerlikler bulunmuştur. Kontrollü laboratuvar koşullar altında lüsterin yeniden üretimine yönelik daha önceki çalışmalarla arkeolojik verilerin lüster üretiminin tarihsel teknolojik yönlerine nasıl 1şık tuttuğu gösterilmektedir. Sınırlı sayıda örnekle bu dönemde lüster üretimleri arasında önemli farklılıklar ve benzerlikler ortaya çıkarılmış, değişikliklerin olası nedenleri tartışılmıştır. İncelenen Mısır, Suriye ve İran lüsterleri sırasıyla Şekil 11-13'de takdim edilmiştir. 
Tablo 6. Örneklerin rengi, parlaklığı, bakır ve gümüş oran1 [36]

\begin{tabular}{|c|c|c|c|c|c|c|c|}
\hline Örnek & Tipoloji & $\begin{array}{l}\text { Dağılmış } \\
\text { Yansımada } \\
\text { Renk }\end{array}$ & $\begin{array}{l}\text { Yansımış } \\
\text { Yansımada } \\
\text { Renk } \\
\end{array}$ & $\begin{array}{l}\mathrm{Cu} /(\mathrm{Cu}+\mathrm{Ag}) \\
\text { ağırlık] }\end{array}$ & SD & $\lambda_{\mathrm{D}}$ & p.e. \\
\hline JR02 & $\begin{array}{l}\text { Lüster } \\
\text { seramik }\end{array}$ & $\begin{array}{lll}\text { Altın sarısı ve } \\
\text { yeşil }\end{array}$ & $\begin{array}{ll}\text { Altın } & \text { ve } \\
\text { morumsu } & \\
\end{array}$ & 0,078 & 0,056 & 583 & 0,59 \\
\hline JR01 & $\begin{array}{l}\text { Lüster } \\
\text { seramik }\end{array}$ & Altın sarısı & Altın & 0,27 & 0,18 & 583 & 0,21 \\
\hline OX957 & $\begin{array}{l}\text { Lüster } \\
\text { seramik }\end{array}$ & $\begin{array}{l}\text { Toprak sarısı ve } \\
\text { yeşil }\end{array}$ & $\begin{array}{ll}\text { Altın } & \text { ve } \\
\text { morumsu } & \\
\text { noktalar } & \\
\end{array}$ & 0,43 & 0,20 & 583 & 0,56 \\
\hline JR06 & $\begin{array}{l}\text { Lüster } \\
\text { seramik }\end{array}$ & $\begin{array}{l}\text { Siyah noktalı } \\
\text { kahverengi }\end{array}$ & $\begin{array}{l}\text { Saçılmış } \\
\text { morumsu noktalı } \\
\text { altın }\end{array}$ & 0,40 & 0,28 & 587 & 0,50 \\
\hline OX9004 & $\begin{array}{l}\text { Lüster } \\
\text { seramik }\end{array}$ & $\begin{array}{l}\text { Siyah noktalar } \\
\text { ile kırmızımsı } \\
\text { kahverengi }\end{array}$ & $\begin{array}{l}\text { Saçılmış } \\
\text { morumsu noktalı } \\
\text { altın }\end{array}$ & 0,41 & 0,34 & 588 & 0,47 \\
\hline OX955 & $\begin{array}{l}\text { Lüster } \\
\text { seramik }\end{array}$ & Kahverengi & $\begin{array}{l}\text { Birkaç morumsu } \\
\text { noktalı altın }\end{array}$ & 0,59 & 0,22 & 585 & 0,50 \\
\hline OX933 & $\begin{array}{l}\text { Lüster } \\
\text { seramik }\end{array}$ & Kahverengi & $\begin{array}{l}\text { Birkaç morumsu } \\
\text { noktalı altın }\end{array}$ & 0,58 & 0,22 & 586 & 0,44 \\
\hline JR03 & $\begin{array}{l}\text { Lüster } \\
\text { seramik }\end{array}$ & Kahverengi & $\begin{array}{l}\text { Birkaç morumsu } \\
\text { noktalı altın }\end{array}$ & 0,60 & 0,16 & 587 & 0,42 \\
\hline OX936 & $\begin{array}{l}\text { Lüster } \\
\text { seramik ve } \\
\text { kobalt mavi } \\
\end{array}$ & Kahverengi & $\begin{array}{l}\text { Birkaç morumsu } \\
\text { noktalı altın }\end{array}$ & 0,76 & 0,09 & 587 & 0,56 \\
\hline OX944 & $\begin{array}{l}\text { Lüster } \\
\text { seramik }\end{array}$ & $\begin{array}{l}\text { Kirmızıms1 } \\
\text { kahve }\end{array}$ & $\begin{array}{l}\text { Birkaç morumsu } \\
\text { noktalı altın }\end{array}$ & 0,82 & 0,07 & 588 & 0,56 \\
\hline OX946 & $\begin{array}{l}\text { Lüster } \\
\text { seramik }\end{array}$ & Kahverengi & $\begin{array}{l}\text { Birkaç morumsu } \\
\text { noktalı altın }\end{array}$ & 0,81 & 0,09 & 589 & 0,53 \\
\hline JR04 & $\begin{array}{l}\text { Lüster } \\
\text { seramik }\end{array}$ & $\begin{array}{l}\text { Kırmızıms1 } \\
\text { kahve }\end{array}$ & $\begin{array}{l}\text { Birkaç morumsu } \\
\text { noktalı altın }\end{array}$ & 0,80 & 0,06 & 590 & 0,46 \\
\hline JR05 & $\begin{array}{l}\text { Lüster } \\
\text { seramik }\end{array}$ & $\begin{array}{l}\text { Kirmızımsı } \\
\text { kahve }\end{array}$ & $\begin{array}{l}\text { Kırmızıms1, altın } \\
\text { ve morumsu } \\
\text { noktalar }\end{array}$ & 0,71 & 0,08 & 591 & 0,25 \\
\hline Yeşil & $\begin{array}{l}\text { Yeşil bakır } \\
\text { seramik }\end{array}$ & Yeşil & - & 1 & 0,28 & 549 & 10,95 \\
\hline Mavi & $\begin{array}{l}\text { Kobalt mavi } \\
\text { seramik }\end{array}$ & Mavi & - & - & - & 455 & 7,36 \\
\hline Kahverengi & $\begin{array}{l}\text { Saydam sirlı } \\
\text { seramik }\end{array}$ & Kahverengi & - & - & - & 585 & 53,46 \\
\hline
\end{tabular}

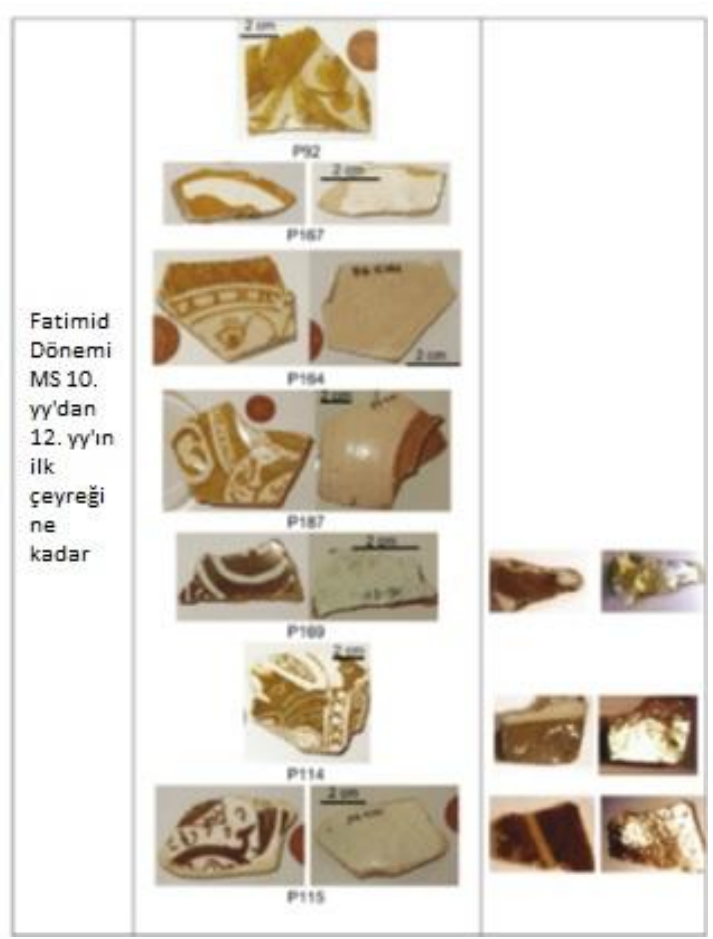

Şekil 11. Misır lüsterleri [37]. 


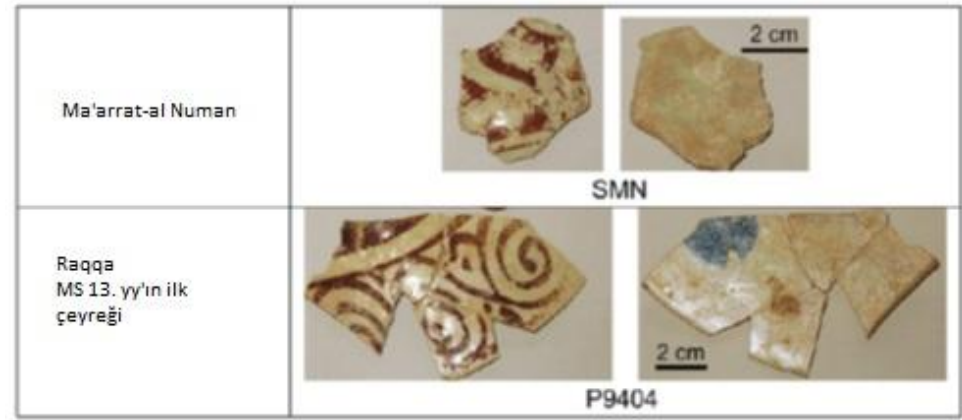

Şekil 12. Suriye lüsterleri [37].

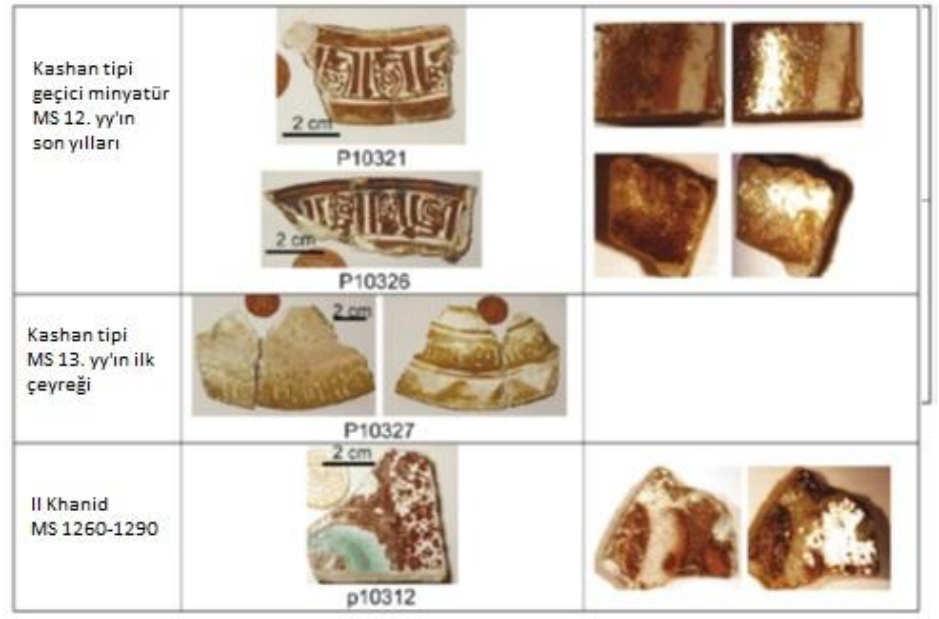

Şekil 13. İran lüsterleri [37].

Tablo 7. Lüster katmanlarının bileșiminin özeti [37]

\begin{tabular}{|c|c|c|c|c|c|c|c|c|c|c|}
\hline Bölge & Örnek No & Renk & Metalik parlaklık & & $\begin{array}{l}\text { anal } \\
\mathrm{Cu}\end{array}$ & $\begin{array}{l}\text { i \% ağ. } \\
\text { Ag }\end{array}$ & $\begin{array}{l}\% \\
\mathrm{Cu} /(\mathrm{Cu}+\mathrm{Ag})\end{array}$ & $\begin{array}{l}\text { Oksitlenme } \\
\text { durumu }\end{array}$ & $\begin{array}{l}\text { Nano } \\
\text { parçacıklar }\end{array}$ & $\begin{array}{l}\begin{array}{l}\text { Boyut } \\
\text { (nm) }\end{array} \\
\end{array}$ \\
\hline \multirow[t]{7}{*}{ Misır } & P92 & Sar1/yeşilimsi & Hayır & 28 & 0,25 & 2,00 & 11 & $\%$ at. $100 \mathrm{Ag}^{\circ}$ & $\mathrm{Ag}$ & $12(4)$ \\
\hline & P167 & Koyu sarı & Hayır & 48 & 0,24 & 2,86 & 8 & $\%$ at. $100 \mathrm{Ag}^{\circ}$ & $\mathrm{Ag}$ & $17(4)$ \\
\hline & P164 & Koyu sarı & Hayır & 44 & 1,77 & 4,00 & 31 & & $\mathrm{Ag}$ & \\
\hline & $\mathrm{P} 187$ & Sar1/yeşilimsi & Hayır & 43 & 1,02 & 4,35 & 21 & & $\mathrm{Ag}$ & $20(4)$ \\
\hline & P114 & Yeşil/kahverengi & Altın & 43 & 1,02 & 3,47 & 23 & & $\mathrm{Ag}$ & $20(7)$ \\
\hline & P115 & Kahverengi & Altın & 35 & 0,46 & 5,43 & 8 & $\% 100 \mathrm{Ag}^{\circ}$ & $\mathrm{Ag}$ & \\
\hline & P169 & $\begin{array}{l}\text { Kırmızı kenar } \\
\text { Kahverengi }\end{array}$ & $\begin{array}{l}\text { Hayır } \\
\text { Altın }\end{array}$ & $\begin{array}{l}6 \\
27 \\
\end{array}$ & $\begin{array}{l}1,90 \\
0,56\end{array}$ & $\begin{array}{l}1,85 \\
7,55\end{array}$ & $\begin{array}{l}51 \\
7 \\
\end{array}$ & & $\begin{array}{l}\mathrm{Cu}_{2} \mathrm{O} \\
\mathrm{Ag}\end{array}$ & \\
\hline \multirow[t]{2}{*}{ Suriye } & SMN & K1rmız1 & Hayır & 25 & 6,36 & n.d. & 100 & $\% 58 \mathrm{Cu}^{+}-\mathrm{Cu}^{\circ}$ & $\mathrm{Cu}$ & $9(3)$ \\
\hline & P9404 & Kahverengi & Hayır & 9 & 6,88 & 2,85 & 71 & $\begin{array}{l}\% \quad 82 \mathrm{Cu}^{+}- \\
\mathrm{Cu}^{\circ}, \mathrm{Cu}^{+2}\end{array}$ & $\begin{array}{ll}\mathrm{Cu}, & \mathrm{Cu}_{2} \mathrm{O}, \\
\mathrm{Ag} & \\
\end{array}$ & \\
\hline \multirow[t]{4}{*}{ İran } & P10326 & $\begin{array}{l}\text { Kırmızı kenar } \\
\text { Kahverengi }\end{array}$ & $\begin{array}{l}\text { Hayır } \\
\text { Altın }\end{array}$ & $\begin{array}{l}17 \\
65\end{array}$ & $\begin{array}{l}1,90 \\
3,57\end{array}$ & $\begin{array}{l}0,14 \\
2,73\end{array}$ & $\begin{array}{l}93 \\
57\end{array}$ & $\% 60 \mathrm{Cu}^{+}-\mathrm{Cu}^{\circ}$ & $\begin{array}{l}\mathrm{Cu} \\
\mathrm{Ag}\end{array}$ & $9(3)$ \\
\hline & P10321 & $\begin{array}{l}\text { Kırmızı kenar } \\
\text { Kahverengi }\end{array}$ & $\begin{array}{l}\text { Hayır } \\
\text { Altın }\end{array}$ & $\begin{array}{l}33 \\
49\end{array}$ & $\begin{array}{l}3,41 \\
2,46\end{array}$ & $\begin{array}{l}1,26 \\
3,68\end{array}$ & $\begin{array}{l}73 \\
40\end{array}$ & $\begin{array}{lrr}\% & 76 & \mathrm{Cu}^{+}- \\
\mathrm{Cu}^{\mathrm{o}}, & \% & 100 \\
\mathrm{Ag}^{\circ} & & \\
\end{array}$ & $\begin{array}{l}\mathrm{Cu} \\
\mathrm{Ag}\end{array}$ & $18(5)$ \\
\hline & $\mathrm{P} 10327$ & Yeşilimsi & Hayır & 36 & 4,37 & 0,78 & 85 & $\% 100 \mathrm{Cu}^{+}$ & $\mathrm{Cu}_{2} \mathrm{O}$ & $27(5)$ \\
\hline & $\mathrm{P} 10312$ & $\begin{array}{l}\text { K1rmızı kenar } \\
\text { Kahverengi }\end{array}$ & $\begin{array}{l}\text { Hayır } \\
\text { Altın }\end{array}$ & $\begin{array}{l}18 \\
16\end{array}$ & $\begin{array}{l}3,4 \\
5,31\end{array}$ & $\begin{array}{l}0,34 \\
4,48\end{array}$ & $\begin{array}{l}91 \\
54\end{array}$ & $\% 62 \mathrm{Cu}^{+}-\mathrm{Cu}^{\circ}$ & $\begin{array}{l}\mathrm{Cu} \\
\mathrm{Ag}\end{array}$ & \\
\hline
\end{tabular}

MS 9. yüzyıla ait ilk Irak üretimleri, farklı renklerde bakır ve gümüş karışımı lüsterlerden yapılmış ve az miktarda kurşun içeren sırlara uygulanmış, ancak arada sırada kendini gösteren bir metalik parlaklık elde edilmiştir. MS 10. yüzyılda yüksek kaliteli, homojen tek renkli altın gümüş zengini lüster ile kurşun açısından zengin sırlar da yapılmış, elde edilen bilgi Irak'tan çömlekçi göçüyle Mısır'a transfer edilmiştir. Fatimi ihtişamı, gümüş zengini bir altın parıltısını mükemmelleştirmek üzere lüster bakımından oldukça zengin kurşun camları üzerinde lüster tekniğinin gelişimine izin vermiştir. Fatimi lüsterleri, farklı sinterleme koşullarının kullanımıyla ilgili olabilecek renk değişimlerini göstermektedir. Daha sonradan ortaya çıkan çömlekçilerin Suriye'ye (TellMinis), İran'a ve diğer yerlere (özellikle İspanya) göçü, İslam teknolojisini tüm dünyaya yaymıştır. İran 
lüsterlerinin etkilerini gösteren Kuzey Suriye yapımları daha düşük maliyetli malzemeler ve sınırlı bir süreç bilgisi kullanılarak geliştirilmiştir. Bahsi geçen lüsterler, bakır esaslı kırmızı yakut ve bakır/gümüş çikolata kahverenginde olup metalik parlaklıktan yoksundur. Daha sonraki İran ve İspanyol üretimleri Fatimi çömlekçilerinin metalik 1şıltılı kahverengi-altın ve kırmızı kenarlı lüsterlerini üretmek için geliştirdikleri tekniklere güçlü bağlar sergilemektedir. MS 9. ve 10. yüzyıllarda Irak’ta lüsterin keşfi Pradell vd. tarafından incelenmiştir [2]. Bu çalışmada MS. 9. yüzyıla ait polikrom ve Irak'tan MS. 10. yüzyıla ait tek renkli lüster içeren dört önemli lüster örneği araştırılmıştır. Seçilen örnekler bilinen en erken lüster üretimini temsil etmektedir. İlgili dört lüsterin ön ve arka kısımlarından çekilen resimleri Şekil 14'te verilmiştir.

MS 9. yüzyıla ait Irak lüsterleri alkali-kurşun içeren, kalayla opaklaştırılmış sır üzerine $\mathrm{Cu}$ ve $\mathrm{Ag}$ bileşikleri karışımının kullanımıyla elde edilmiştir. Kehribar ve koyu kahverengi lüster tabakasında büyük miktarda gümüş nano-parçacıkların ve sır içinde çözünmüş $\mathrm{Cu}^{+}$ve $\mathrm{Cu}^{+2}$ 'nin bulunduğu ortaya konulmuştur. MS 9. yüzyıla ait bazı lüsterlerin karakteristik özelliklerinin ve MS 10. yüzyıla ait tek renkli Irak orijinli üretimin yeşil renk özelliği, bakırsız, gümüş zengini lüsterlerde (veya en azından çok düşük $\mathrm{Cu}$ içeren lüsterlerde) sağlanmıştır. $\mathrm{Cu} / \mathrm{Ag}$ karma veya $\mathrm{Ag}$ zengini lüsterlerin eldesi için, daha az indirgenme koşullarına ihtiyaç vardır. Neticede de çok çeşitli renkler üretilmiştir. Irak'tan önceki İslami lüsterlerin analizi gümüş zengini yeşil lüsterlerde metal yansıma elde edildiğini, ancak bunun nispeten düşük $\mathrm{PbO}$ içeren sırlarda (\% 10-15), karışı $\mathrm{Cu} / \mathrm{Ag}$ kehribar ve kahverengi lüsterlerde gerçekleşmediğini göstermektedir (Şekil 15).

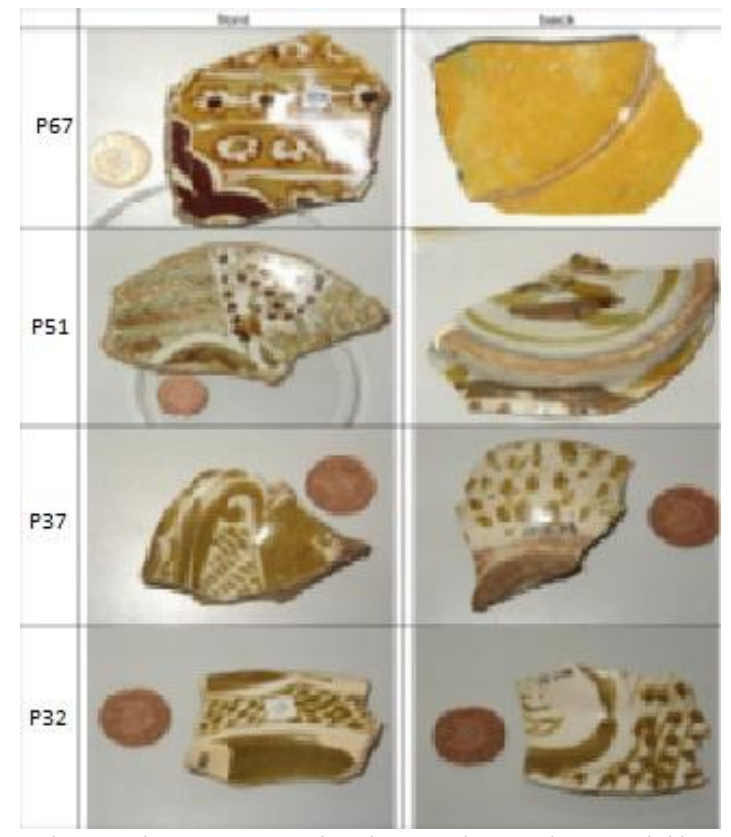

Şekil 14. Dört lüsterin ön ve arka kısımlarından çekilen resimler [2].

İslamik lüster teknolojisi Pradell vd. tarafından araştırılmış [38-39], farklı pigment, sır bileşimleri, 1sıl yollar ve atmosferler kullanılarak üretilen lüster katmanlarının özellikleri özetlenmiştir. Üretimlerin mikro-yapısal, kimyasal ve optik özelliklerinin analizi farklı renk ve parlaklıklara sahip lüster katmanlarının üretimi için gerekli koşullara geniş bir bakış açısı sağlamıştır.

Lüster üretiminin başlangıcından (Irak 9. ve 10. yüzyıl), Fatimi (Mısır 11.-12. yüzyıl) ve daha sonra Suriye ve Fars (MS 12.-13. yüzyıl) yapımlarından kaynaklanan parlaklık sürecinde gerekli değişiklikler ve iyileştirmeler değerlendirilmiştir (Şekil 16). 


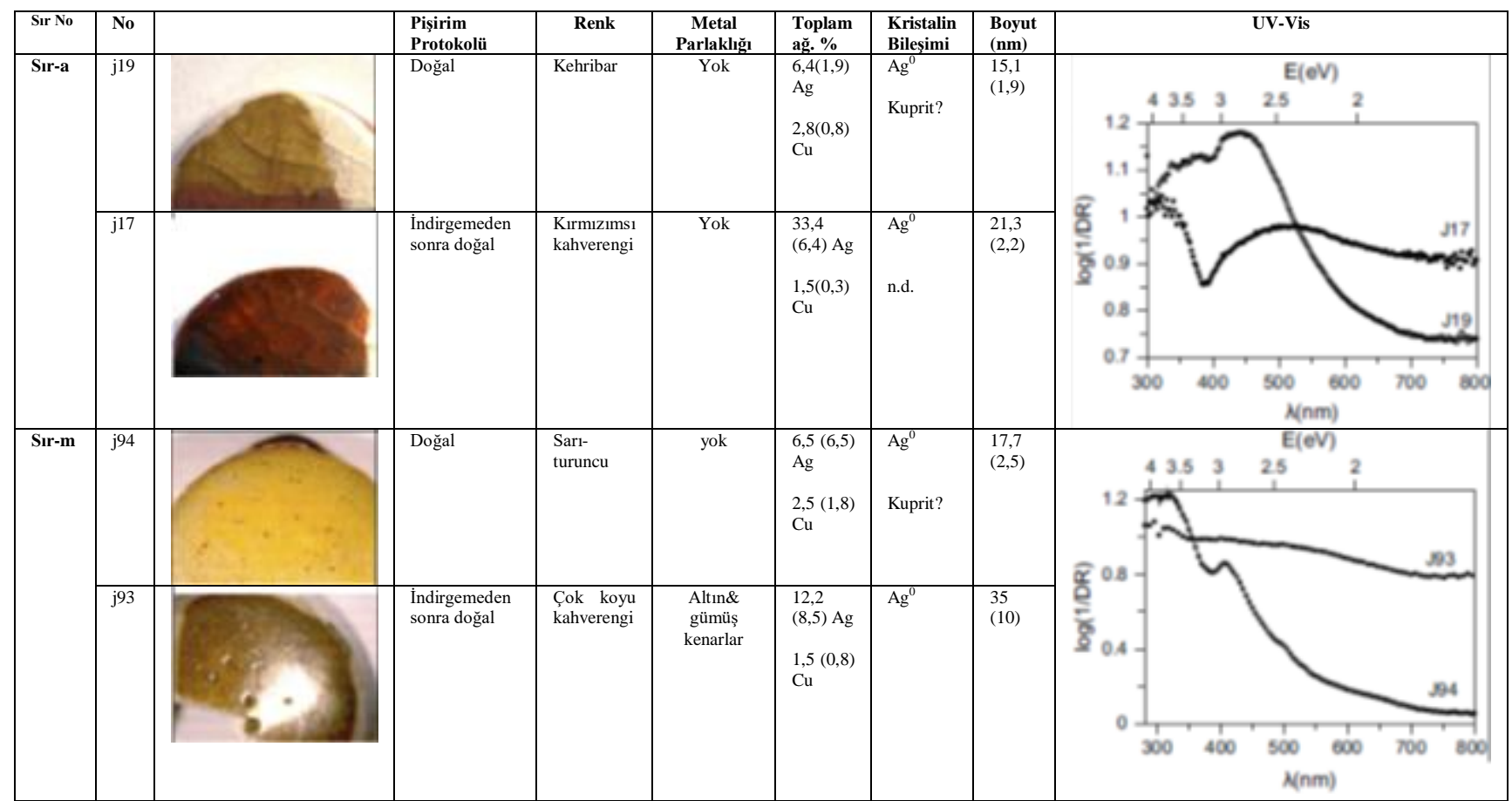

Şekil 15. Laboratuvar ortamında çoğaltılan örnekler için elde edilen verilerin özeti [2].

Tablo 8. İslami sırların ve lüster katmanlarının kimyasal analizi [2]

\begin{tabular}{|c|c|c|c|c|c|c|c|c|c|c|c|c|c|c|c|c|}
\hline & & & & $\mathrm{N}$ & $\mathrm{Na}_{2} \mathrm{O}$ & $\mathrm{K}_{2} \mathrm{O}$ & $\mathrm{Al}_{2} \mathrm{O}_{3}$ & $\mathrm{SiO}_{2}$ & $\mathrm{CaO}$ & $\mathrm{MgO}$ & $\mathrm{FeO}$ & $\mathrm{TiO}_{2}$ & $\mathrm{Cu}$ & $\mathrm{Ag}$ & $\mathrm{PbO}$ & $\mathrm{SnO}_{2}$ \\
\hline \multirow[t]{3}{*}{$\begin{array}{l}\text { Çok } \\
\text { renkli } \\
\text { MS } 9 . \\
\text { yy }\end{array}$} & $\begin{array}{l}\text { P-67 } \\
\text { (geri) }\end{array}$ & $\begin{array}{l}\text { Sir yüzey } \\
\text { kesiti } \\
\text { Turuncu } \\
\text { kehribar } \\
\text { lüster }\end{array}$ & $\begin{array}{l}250-300 \\
\mu \mathrm{m}\end{array}$ & . & 6,42 & 5,90 & 1,82 & 64,17 & $\begin{array}{l}\text { b.l.d } \\
4,12\end{array}$ & 4,00 & 0,30 & 0,14 & b.l.d & b.l.d & 4,33 & 1,01 \\
\hline & $\begin{array}{l}\text { P-67 } \\
\text { (ön) }\end{array}$ & $\begin{array}{l}\text { Sir yüzey } \\
\text { kesiti } \\
\text { Koyu } \\
\text { kahveren } \\
\text { gi lüster }\end{array}$ & $\begin{array}{l}300-400 \\
\mu \mathrm{m} \\
\text { Ametal }\end{array}$ & 41 & $\begin{array}{l}7,16 \\
0,75\end{array}$ & $\begin{array}{r}4,36 \\
1,61\end{array}$ & $\begin{array}{l}2,34 \\
1,33\end{array}$ & $\begin{array}{l}64,04 \\
61,32\end{array}$ & $\begin{array}{l}\text { b.l.d } \\
9,34\end{array}$ & $\begin{array}{l}3,91 \\
11,55\end{array}$ & $\begin{array}{l}0,25 \\
0,65\end{array}$ & 0,09 & $\begin{array}{l}\text { b.l.d. } \\
9,34\end{array}$ & $\begin{array}{l}\text { b.l.d } \\
11,55\end{array}$ & $\begin{array}{l}6,86 \\
4,80\end{array}$ & $\begin{array}{l}2,63 \\
2,11\end{array}$ \\
\hline & P-51 & $\begin{array}{l}\begin{array}{l}\text { Sir yüzey } \\
\text { kesiti }\end{array} \\
\text { Yeşil } \\
\text { lüster } \\
\text { Kehribar } \\
\text { lüster } \\
\end{array}$ & $\begin{array}{l}\text { Metal } \\
\text { Ametal }\end{array}$ & 24 & $\begin{array}{r}, 83 \\
1,65 \\
1,86\end{array}$ & $\begin{array}{r}4,83 \\
2,75 \\
2,83\end{array}$ & $\begin{array}{l}2,92 \\
1,62 \\
1,67\end{array}$ & $\begin{array}{r}60,94 \\
72,30 \\
74,23 \\
\end{array}$ & $\begin{array}{r}\text { b.l.d } \\
2,39 \\
4,06\end{array}$ & $\begin{array}{l}2,40 \\
4,11 \\
0,61\end{array}$ & 0,75 & 0,10 & $\begin{array}{l}\text { b.l.d. } \\
2,39\end{array}$ & $\begin{array}{l}\text { b.l.d } \\
4,11 \\
0,61\end{array}$ & $\begin{array}{l}13,87 \\
5,62 \\
5,61\end{array}$ & $\begin{array}{l}, 02 \\
1,93 \\
2,24\end{array}$ \\
\hline \multirow[t]{2}{*}{$\begin{array}{l}\text { Tek } \\
\text { renkli } \\
\text { MS } \\
10 . \text { yy }\end{array}$} & P-37 & $\begin{array}{l}\begin{array}{l}\text { Sir yüzey } \\
\text { kesiti }\end{array} \\
\text { Sir yüzeyi } \\
\text { Yeşil } \\
\text { lüster }\end{array}$ & $\begin{array}{l}300-400 \\
\mu \mathrm{m}\end{array}$ & $\begin{array}{l}24 \\
29\end{array}$ & $\begin{array}{l}6,47 \\
4,21 \\
3,51\end{array}$ & $\begin{array}{l}4,68 \\
4,42\end{array}$ & $\begin{array}{l}2,07 \\
1,81\end{array}$ & $\begin{array}{r}63,90 \\
67,78 \\
67,29 \\
\end{array}$ & $\begin{array}{l}\text { b.l.d } \\
\text { b.l.d } \\
\text { b.l.d }\end{array}$ & $\begin{array}{l}2,74 \\
1,32\end{array}$ & $\begin{array}{l}0,87 \\
0,85\end{array}$ & $\begin{array}{l}0,10 \\
0,12\end{array}$ & $\begin{array}{l}\text { b.l.d } \\
\text { b.l.d }\end{array}$ & $\begin{array}{l}\text { b.l.d } \\
3,40\end{array}$ & $\begin{array}{l}5,60 \\
5,18\end{array}$ & $\begin{array}{l}2,50 \\
2,59\end{array}$ \\
\hline & P-32 & $\begin{array}{l}\text { Sir yüzey } \\
\text { kesiti } \\
\text { Sir yüzeyi } \\
\text { Yeşil } \\
\text { lüster }\end{array}$ & $\begin{array}{l}300-400 \\
\mu \mathrm{m}\end{array}$ & 35 & $\begin{array}{l}4,98 \\
2,20 \\
1,44\end{array}$ & $\begin{array}{l}3,88 \\
3,14\end{array}$ & $\begin{array}{l}2,25 \\
2,19\end{array}$ & $\begin{array}{l}60,18 \\
69,54 \\
67,35\end{array}$ & $\begin{array}{l}\text { b.l.d } \\
0,13 \\
0,36\end{array}$ & $\begin{array}{l}0,22 \\
4,03\end{array}$ & $\begin{array}{l}0,62 \\
0,61\end{array}$ & 0,08 & b.l.d & $\begin{array}{l}0,22 \\
4,03\end{array}$ & $\begin{array}{l}10,66 \\
10,01\end{array}$ & $\begin{array}{l}2,21 \\
2,98 \\
2,66\end{array}$ \\
\hline
\end{tabular}

Ortaçağ tarifleri ve prosedürlerine dayanarak, İslami lüsterde gözlenen parlak renkler ve parıltılar yeniden üretilmiştir. Bu süreç, tarihi yapılarda bulunan farklı görsel etkileri üretmek için gerekli malzemeleri ve protokolleri vermiştir. 


\begin{tabular}{|c|c|c|}
\hline $\begin{array}{l}\text { Sir } \\
\text { Nano Parçacıkların Boyutu } \\
\text { Boyut Dağılımı }\end{array}$ & $\begin{array}{l}\text { Kurşunsuz } \\
10-20 \mathrm{~nm} \\
\text { Homojen } \\
\end{array}$ & $\begin{array}{l}\% 32 \mathrm{PbO} \\
3-50 \mathrm{~nm} \\
\text { Heterojen }\end{array}$ \\
\hline \multirow[t]{2}{*}{$\mathrm{Cu}^{0}$ ve küprit } & & \\
\hline & J6 & J65 \\
\hline \multirow[t]{2}{*}{$\mathrm{Ag}^{0}$} & & \\
\hline & J126 & J76 \\
\hline \multirow[t]{2}{*}{ Küprit, $\mathrm{Cu}^{+2}$ ve $\mathrm{Ag}^{0}$} & & \\
\hline & $\mathrm{J17}$ & $J 93$ \\
\hline
\end{tabular}

Şekil 16. Bakır, gümüş ve bakır-gümüş karışımı lüster örnekleri [38-39].

Sonuçlar, kurşun-esaslı sır kullanımının metalik parlaklığın gelişiminde esas olduğunu ve bunun da ilk kez Abbasi'den daha sonraki İslami ürünlerde görüldügünü vurgulamaktadır. Modern seramik sırlarında lüster için seryum dioksit içeren renkli cam tozunun kullanımın etkileri Siligardi vd. tarafından incelenmiştir [40]. Endüstriyel firınlama ile elde edilen sırlar, $\mathrm{x}-1$ şını foto elektron spektroskopisi, $\mathrm{x}$-1şını kırınımı (XRD) ve enerji-saçınım spektroskopisi ile SEM kullanılarak analiz edilmiş, yüzeydeki lüster etkisinin mekanizması açıklanmıştır. Sonuçlar, sırın özellikle çok ince bir $\mathrm{CeO}_{2}$ kristal tabakasının oluşumu ile ilişkili yanardöner renkler ortaya koyduğunu göstermiştir. Dahası, $\mathrm{CeO}_{2}$ kristalleri tercihli bir yönelim ve farklı boyutlar sergilemiştir. Sır üzerindeki $\mathrm{CeO}_{2}$ kristallenmesi de sıcak evre $\mathrm{x}-1$ şını tekniği kullanılarak incelenmiştir.

Tablo 9. İncelenen camların ısıl özellikleri [40]

\begin{tabular}{lccccccc}
\hline Firit & $\mathbf{T}_{\mathrm{g}}\left({ }^{\mathbf{0}} \mathbf{C}\right)$ & $\boldsymbol{\alpha}\left({ }^{\mathbf{0}} \mathbf{C}^{-1}\right)$ & $\begin{array}{l}\mathbf{T}_{\text {sinterleme }} \\
\left({ }^{\mathbf{0}} \mathbf{C}\right)\end{array}$ & $\begin{array}{l}\mathbf{T}_{\text {yumuşama }} \\
\left({ }^{\circ} \mathbf{C}\right)\end{array}$ & $\mathbf{T}_{\text {küre }}\left({ }^{\mathbf{0}} \mathbf{C}\right)$ & $\begin{array}{l}\mathbf{T}_{\text {yarm }} \\
\left({ }^{\circ} \mathbf{C}\right)\end{array}$ & $\begin{array}{l}\mathbf{T}_{\text {erime }} \\
\mathbf{1 / 3} \text { küre }\end{array}\left({ }^{\text {veya }} \mathbf{C}\right)$ \\
\hline F1 & 610 & $7,3 \times 10^{-6}$ & 814 & 948 & 1042 & 1150 & 1198 \\
\hline
\end{tabular}

Renkli lüster etkisinin esas olarak sır yüzeyindeki seryum dioksit kristal tabakasının yansıma özelliklerinden kaynaklandığı tespit edilmiştir. Yüzeyin mikro-yapısı oldukça heterojendir; bazı bölgelerde çok küçük kristaller $(<200 \mathrm{~nm}$ ) veya daha büyük kübik kristaller (yaklaşık 0,5 mm), diğer bölgelerde camsı bir yapı mevcuttur. Lüster etkisinin görünür ışıla (saçılma olayı) etkileşime ve estetik özellikleri değiştirebilen kristallerin boyutuna bağlı olabileceği belirtilmiştir. Parlatma sonrası sırların yüzeyinin esasen camsı olduğu, küçük kuvars ve zirkon (zirkonyum silikat) kristalleri görülse de herhangi bir lüster etkisine rastlanmamıştır. Bu sonuca göre, kristalleşmenin sır yüzeyinde meydana geldiği ve estetik özelliklerin yüzey kristalleşmesiyle ilişkili olduğu doğrulanmıştır.

Bir başka çalışmada ise Gutierrez vd. tarafından gümüş İslami lüsterinin rengi ve altın parıltısı incelenmiştir [41]. İslami Dönemlerin (MS 9.-12. yy) sırlı seramik üzerine altın benzeri lüster süslemeleri, gümüş metal nano-parçacıklarının nano-kompozit tabakasından meydana gelmektedir. 
Bulgular, İslami Dönemlerde ulaşılan yüksek teknolojik seviyeye yeni bakış açısı getirmekte, aynı zamanda önemli tarihsel etkileri de içermektedir. Bu, ilgili dönemde sırların zenginleşmesine dair yeni ipuçları vermekte ve Orta Çağ simyasının üretimi için bazı temelleri ortaya koymaktadır. Gümüş lüsterin altın metalik parlaklığı sadece yoğun nano-parçacıklardan elde edilmiş tabakalarda meydana gelmektedir. Yansıtma gücünün katmandaki nano-parçacıkların miktarının arttırılmasına, genişlemesine ve kırmızıya kaymasına neden olduğu bulunmuştur. Böylece, yansıyan ışı̆̆ın rengi maviden yeşil-sarıya (altın etkisi) kaymaktadır (Şekil 17).

Mestre vd. tarafından gümüş nano-parçacık temelli bir sarı seramik pigmentinin geliştirilmesi için çalışmalar yürütülmüştür [42]. Hammadde olarak gümüş nitrat ve polivinil pirolidon kullanılarak sulu fazda kimyasal indirgeme yöntemi ile sentezlenen gümüş nano-parçacıklara dayanan üçüncü alev seramik süslemeleri için sarı bir pigment elde edilmiştir. İncelenen sırın parlatılmış çapraz kesitinde küresel kromofor parçacıklarının görülebildiği pigment tabakası Şekil 18'de sunulmuştur. Şelit-esaslı camlarda lüster oluşum mekanizması Gualtieri vd. tarafından incelenmiş [43], tekpişirim duvar karoları için şelit-esaslı camların lüster etkisinden sorumlu mekanizma açıklanmıştır. Yüzey dekorasyonu, tek-pişirim duvar karoları (50 dakika boyunca maksimum $1130{ }^{\circ} \mathrm{C}$ 'de) için bir $\mathrm{Si}-\mathrm{Ca}-\mathrm{Zn}-\mathrm{Al}-\mathrm{K}-\mathrm{B}$ cam tozu ve zirkonyumlu altlıklar üzerinde ağırlıkça $\% 10 \mathrm{WO}_{3}$ 'den oluşan ince bir film ile elde edilmiştir. Gözlenen lüster etkisi elmas gibi parlak, sert ve sedeflidir. Zira yüzeydeki şelit nano-kristalleri nispeten yüksek kırınım indisi $(n=1,93)$ ile 1 şığın kayda değer biçimde yansımasına yol açmaktadır. Parlaklık ayrıca sedeflidir çünkü yüzeye paralel (004) düzlemde bulunan nano-kristaller altta uzanan camsı tabaka $(n=1,5)$ ile etkileşime girerek rastgele dağılmış şelit kristallerini oluşturmaktadır. Metal-cam seramik kompozitlerde yaygın parlaklık oluşturan mikro-yapılar Şekil 19'da sunulmuştur. Tek kademeli duvar karoları için şelit-esaslı camların parlaklık etkisinin niteliği açıklığa kavuşturulmuştur. Gözlenen parlaklık etkisinin $\mathrm{Ca}-$ esaslı bir renkli cam tozundan ve $1130{ }^{\circ} \mathrm{C}^{\prime}$ de $\mathrm{WO}_{3}$ 'ten nano-fazlı şelitin yüzey kristalleşmesinden kaynaklandığı bulunmuştur. Şelit nano-kristallerinin hesaplanan izotropik kristal boyutu, kırınım çalışmasıyla $96 \mathrm{~nm}$ ve TEM boyutu analiziyle $83 \mathrm{~nm}$ olarak belirlenmiştir.

Son yıllarda yapılan bir başka çalışmada ise polikrom lüster üretim teknolojisi araştırılmıştır [44]. MS 9. yüzyılda Abbasi Irak'ta çeşitli renk ve parlaklık kombinasyonlarına sahip polikrom lüster gereçleri üretilmiştir. Üç renk kombinasyonu (siyah+kırmızı, beyaz-gümüş+kırmızı-sarı ve sarıaltın+kırmızı-bakır) incelenmiş ve üretim malzemeleri ile ölçüleri belirlenmiştir. Gümüş lüsterlerin siyah, beyaz, sarı ve yeşil renkleri, nano-parçacıkların farklı boyutlarıyla ve tabakadaki dağılımlarıyla ilişkilidir. Kurşun ve kalayın sır içerisine dâhil edilmeleri, kırmızı-sarı ve sarı-altın parlaklık üretiminde önemli bir faktör olarak bulunmuştur. Şekil 20'de MS 9. yüzyıldan itibaren çalışılan Irak polikrom lüster örnekleri gösterilmiştir. 


\begin{tabular}{|c|c|c|c|c|c|c|c|}
\hline \multicolumn{4}{|l|}{ Numune } & \multicolumn{3}{|c|}{ Sir } & Lüster Katmanı \\
\hline & Referans & $\operatorname{Renk} \lambda_{d}(\mathrm{~nm})^{3}$ & Parlaklık & $\begin{array}{c}\text { PbO (Kütlece } \\
\% \text { ) }\end{array}$ & $\begin{array}{c}\text { Yoğunluk } \\
\left(\mathrm{g} / \mathrm{cm}^{3}\right)\end{array}$ & $\begin{array}{c}\text { Yansitma } \\
\text { İndisi }\end{array}$ & \\
\hline \multirow{4}{*}{$\begin{array}{l}\text { Abbasi Irak } \\
\text { (MS 9. yy) }\end{array}$} & P67b & $\begin{array}{c}\text { Kahverengi } \\
587,8\end{array}$ & $\begin{array}{c}4+1 \\
4=3 \\
\text { Altın olmayan } \\
\text { mavimsi }\end{array}$ & $6,9(0,3)$ & 2,51 & 1,52 & $\begin{array}{l}\text { at } \% 100 \mathrm{Ag}^{0} \\
\text { At } \% 12 \mathrm{Cu}^{+2}-\text { at } \% 82 \\
\mathrm{Cu}^{+}\end{array}$ \\
\hline & P67a & Sar1 579,0 & Altın olmayan & $4,3(0,7)$ & 2,49 & 1,52 & $\begin{array}{l}\text { at } \% 100 \quad \mathrm{Ag}^{0} \text { at } \% 3 \\
\mathrm{Cu}^{+2}-\text { at } \% 97 \mathrm{Cu}^{+}\end{array}$ \\
\hline & P51b & $\begin{array}{c}\text { Koyu yeşil } \\
575,3\end{array}$ & Altın & \multirow[t]{2}{*}{$13,9(2,1)$} & \multirow[t]{2}{*}{2,50} & \multirow[t]{2}{*}{1,54} & $\begin{array}{l}\text { At } \% 100 \quad \mathrm{Ag}^{0} \text { at } \% 100 \\
\mathrm{Cu}^{+}\end{array}$ \\
\hline & P51a & Yeşil 575,3 & Altın & & & & \\
\hline $\begin{array}{l}\text { Abbasi Irak } \\
\text { (MS 10. yy) }\end{array}$ & P37 & Yeşil 577,3 & Altın olmayan & $7,9(0,4)$ & 2,56 & 1,52 & At $\% 100 \mathrm{Ag}^{0}$ \\
\hline \multirow{3}{*}{$\begin{array}{l}\text { Fatimi Misur } \\
\text { (MS } \\
\text { yy) }\end{array}$} & P99 & Sar1 580,3 & $\begin{array}{c}\text { Altın mavimsi } \\
\text { kenarlı }\end{array}$ & $37,0(3,0)$ & 3,40 & 1,59 & --- \\
\hline & P92 & Yeşil 577,0 & Altın pariltılı & $34,3(1,1)$ & 3,40 & 1,58 & At $\% 100 \mathrm{Ag}^{0}$ \\
\hline & P167 & $\begin{array}{c}\text { Turuncu } \\
581,3\end{array}$ & Altın olmayan & $40,2(2,3)$ & 3,53 & 1,60 & $\begin{array}{l}\text { at } \% 100 \quad \mathrm{Ag}^{0} \quad \text { at } \% 100 \\
\mathrm{Cu}^{+}\end{array}$ \\
\hline
\end{tabular}

Şekil 17. İncelenen gümüş İslami lüster örneği ve özellikleri [41]. 


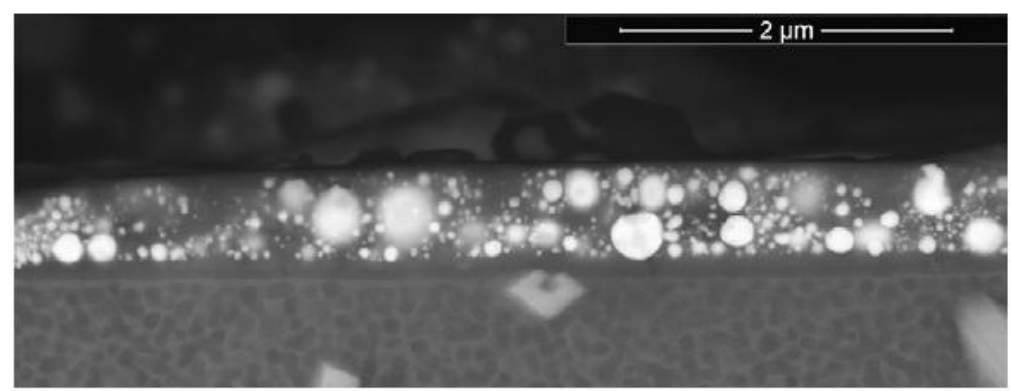

Şekil 18. Sırın parlatılmış çapraz kesitinde küresel kromofor parçacıklarının görülebildiği pigment tabakas1 [42].

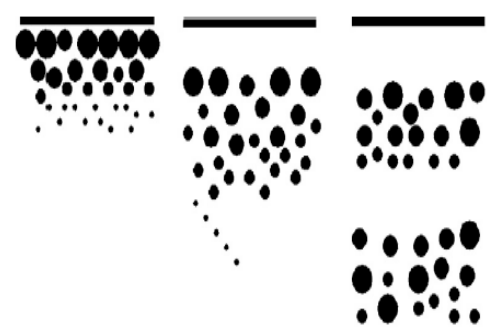

(1)

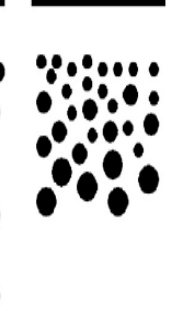

(4)

Şekil 19. Metal-cam seramik kompozitlerde yaygın parlaklık oluşturan mikro-yapılar [43].

Özellikle, aynı nesnede kırmızı-bakır ve sarı-altın süslemeleri birleştiren polikrom lüster, aşağıda belirtilen unsurlarca başarıyla geliştirilmiştir:

(1) Kurşun ve kalay içeren sır üzerinde parlaklık dekorasyonunun uygulanması,

(2) Gümüş zengini lüster karışımının aplikasyonuyla zayıflatılmış güçlü bir indirgeyici atmosfer altında pişirilen, kırmızı bakır zengini lüster karışımının ilk defa uygulanması.

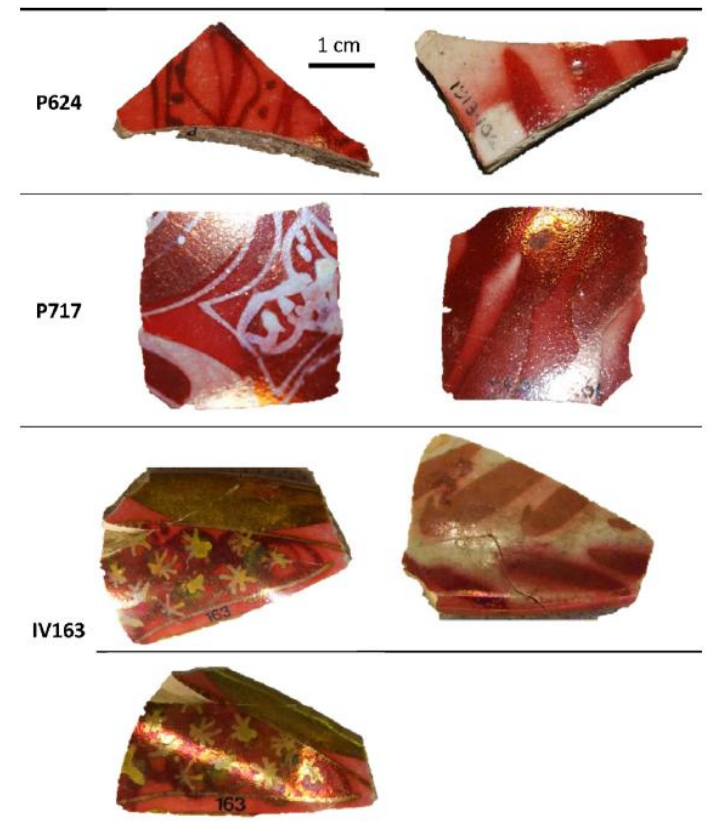

Şekil 20. MS 9. yüzyıldan itibaren çalışılan Irak polikrom lüster örnekleri [44]. 
Tablo 10. Lüster dekorlarının SEM-EDX analizleri [44]

\begin{tabular}{|c|c|c|c|c|c|c|c|c|}
\hline Örnek & $\begin{array}{c}\text { Sir } \\
\text { Kenarı }\end{array}$ & Lüster Renk & Parlaklık & $\mathrm{SnO}_{2}$ & PbO & $\mathrm{Cu}$ & Ag & $\mathrm{Cu} /(\mathrm{Cu}+\mathrm{Ag})$ \\
\hline \multirow[t]{3}{*}{ P624 } & Arka & Kırmız1 & Hayır & 0,5 & 0,3 & 3,7 & 0,9 & 90 \\
\hline & & Siyah & Hayır & b.d. & 0,2 & 2,7 & 2,3 & 44 \\
\hline & Ön & Kirmız1 & Hayır & b.d. & 0,6 & 2,9 & 0,5 & 83 \\
\hline \multirow[t]{4}{*}{ P717 } & Arka & Kirmız1 & Hayır & 0,7 & 0,7 & 2,9 & 0,2 & 94 \\
\hline & & Kirmız1 & Bakır & 0,4 & 1,0 & 5,3 & 0,4 & 93 \\
\hline & & K1rmız1 & Hayır & 3,3 & 10,4 & 3,7 & 0,5 & 89 \\
\hline & & Kırmızı & Bakır & 2,8 & 10,5 & 6,5 & 1,2 & 84 \\
\hline \multirow[t]{3}{*}{ IV163 } & Ön & Sar1 dekorasyon & Altın & 2,5 & 10,7 & 0,9 & 6,3 & 12 \\
\hline & & Sarı kenar & Altın & 2,4 & 9,4 & 0,6 & 6,7 & 8 \\
\hline & & Yeşil & Altın & 2,7 & 10,6 & 1,2 & 7,3 & 15 \\
\hline
\end{tabular}

Razavi vd., Zarinfam tekniği ile opal masa üzerinde lüster sırlarının üretimi, yapısı ve renklerinin karakterizasyonunu ayrıntılı olarak incelemişlerdir [45]. Lüster objeler, belli başlı optik özellikleriyle dikkat çeken seramiklerdir. Bunlardan en önemlisi farklı açılarda farklı renklerde görünen ışıltılarıdır. Söz konusu etki, lüsterin çok katmanlı yapısına ve mine tabakasında metalik nano-parçacıkların varlığına bağlıdır. Zarinfam tekniği ile Mahfam Jam A.Ș.'de üretilen opal sofra takımında lüster sırı üretilmiştir. Numunelerin SEM görüntüsü, sırın, birkaç on nano-metrelik yüzeysel camsı tabaka ve yüzlerce nano-metrelik birleşik bir tabakadan oluşan opal sofra yüzeyi üzerinde çok katmanlı yapı meydana getirdiğini göstermiştir. Çok katmanlı yapı ve gümüş nanoparçacıklar lüster yansımalarına ve renklerine göre önemli role sahiptir. Kompozit tabaka bir silis ortamında gömülü gümüş nano-parçacıklarını içermektedir.

Tablo 11. Sır karışımının kimyasal bileşimi [45]

\begin{tabular}{ccccccccc}
\hline $\begin{array}{c}\text { Sarı } \\
\text { Renkli }\end{array}$ & $\begin{array}{c}\text { Kırmızı } \\
\text { Toprak }\end{array}$ & $\begin{array}{c}\text { Kurşun- } \\
\text { Kalay } \\
\text { Hamuru }\end{array}$ & $\mathrm{FeSO}_{4}$ & Civakrom & $\mathrm{Al}_{\mathbf{2}} \mathrm{O}_{3}$ & $\mathrm{~K}_{\mathbf{2}} \mathrm{CO}_{3}$ & $\mathrm{AgNO}_{3}$ & $\mathrm{CuO}$ \\
\hline 10 & 0,5 & 20,3 & 32 & 2,7 & 20 & 5 & 9 & 0,5 \\
\hline
\end{tabular}

Sarıgüzel vd. farklı sır bileşimlerinin lüsterdeki gümüş ve bakır nano-parçacıkların oluşumu ve özellikleri üzerine etkilerini araştırmışlardır [46]. Lüster sırlı bileşimler (kurşun-alkali ve alkali) ile dekore edilmiş İznik çinileri üzerinde daha fazla bilgi edinilmesi hedeflenmiştir. Öncelikle, yüksek kuvars içeren kurşun-alkali ve alkali-sırlı geleneksel İznik karoları laboratuvar kontrollü koşullar altında üretilmiştir. Isıl işlem sırasındaki sır ve lüster macunu (yükseltgen ve indirgen atmosfer) arasında yer alan iyon değişim mekanizması ile İznik çinileri üzerinde lüster tabakası oluşmuştur. $\mathrm{Ag} / \mathrm{Cu}$ nano-parçacıkları ile lüster katmanlarının bileşimi, doğası ve büyüklüğü, malzemeler üzerinde ileri araştırmalar için kullanılan analitik tekniklerle gerçekleştirilmiştir.

Tablo 12. İznik çinilerinin gövde ve sır katmanlarının bileşimi [46]

\begin{tabular}{|c|c|c|c|}
\hline Bünyenin Hammaddeleri & Ăg. \% & Sir Hammadeleri & Ăg. \% \\
\hline Kuvars & 29 & Kuvars & 44 \\
\hline $\mathrm{Na}-$ feldispat & 28 & $\mathrm{Na}-$ feldispat & 25 \\
\hline $\begin{array}{l}\text { Ufalanmış çanak çömlek } \\
\text { parçaları }\end{array}$ & 12 & Zirkonyum silikat & 10 \\
\hline Cam & 12 & Cam & 6 \\
\hline Kil & 14 & Kil & 8 \\
\hline Cam hamuru & 5 & Cam hamuru & 8 \\
\hline & & Cinko oksit & 3 \\
\hline
\end{tabular}


Tablo 13. WDXRF ile ölçülen İznik çini katmanlarının kimyasal bileşimleri (ağ. \%) [46]

\begin{tabular}{lcccc}
\hline Bileşik & Bünye & Sir & Kurşun-Alkali Sır & Alkali Sır \\
\hline $\mathbf{A l}_{\mathbf{2}} \mathbf{O}_{\mathbf{3}}$ & 9,083 & 6,168 & 0,835 & 8,833 \\
$\mathbf{C a O}$ & 2,352 & 1,053 & 1,336 & 1,218 \\
$\mathbf{F e}_{2} \mathbf{O}_{\mathbf{3}}$ & 0,434 & 0,209 & 0,078 & 0,149 \\
$\mathbf{K}_{\mathbf{2}} \mathbf{O}$ & 0,402 & 0,220 & 0,134 & 3,430 \\
$\mathbf{M g O}$ & 4,978 & 1,437 & 0,470 & 0,492 \\
$\mathbf{N a}_{\mathbf{2}} \mathbf{O}$ & 3,700 & 1,849 & 2,339 & 13,337 \\
$\mathbf{P}_{\mathbf{2}} \mathbf{O}_{\mathbf{5}}$ & 0,050 & 0,082 & - & 0,123 \\
$\mathbf{P b O}$ & 3,941 & 4,041 & 63,222 & 0,234 \\
$\mathbf{S i O}_{\mathbf{2}}$ & 74,383 & 70,356 & 31,385 & 71,686 \\
$\mathbf{T i O}_{\mathbf{2}}$ & 0,126 & 0,071 & - & 0,097 \\
$\mathbf{Z n O}$ & 0,027 & 3,946 & - & 0,006 \\
$\mathbf{Z r O}_{\mathbf{2}}$ & 0,084 & 10,082 & 0,166 & 0,011 \\
\hline
\end{tabular}

İznik çini yüzeylerinde kurşun-alkali sır ve alkali sır üzerindeki lüster tabakaları Şekil 21'de gösterilmiştir.

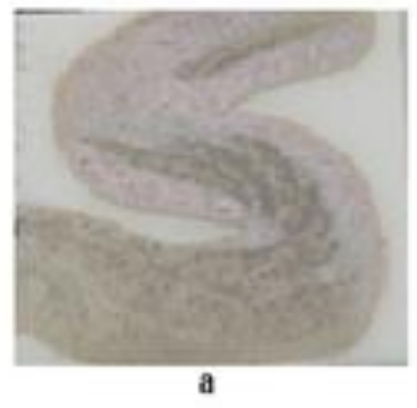

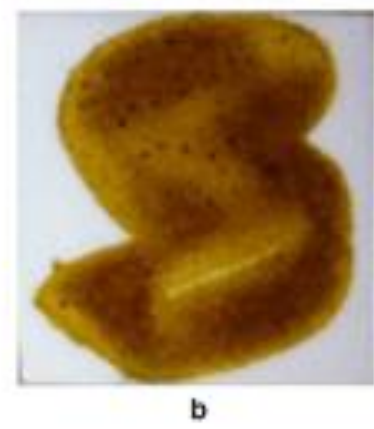

Şekil 21. İznik çini yüzeylerinde (a) kurşun-alkali ve (b) alkali sırr üzerindeki lüster tabakaları [46].

Bu çalışma dekorasyondaki en karmaşık tekniklerden biri olan lüster üzerine kurşun-alkali ve alkali sırlı İznik çinileri ile gerçekleştirilmiştir. Oksitleyici atmosferlerde sinterlenirken sırdaki alkaliler $\left(\mathrm{Na}^{+}\right.$ve/veya $\left.\mathrm{K}^{+}\right)$ile lüsterden $\mathrm{Cu}^{+}$ve $\mathrm{Ag}^{+}$arasındaki iyonik değişimden sonra bir indirgen atmosferin kullanılmasıyla $\mathrm{Ag}^{+}$indirgenir. Camsı yap1 ve metalik gümüşün yanı sıra alkali sırlı karoda bakır oksit tespit edilmiştir. XPS analizi bakırın hem katkılı hem de alkali sırlı İznik karolarında lüster katmanlarıyla kısmen azaldığını ortaya koymuştur.

Sırların teknolojik aktarımının petrografik analizi Ownby vd. tarafından gerçekleştirilmiştir [47]. Biri Mısır'dan diğeri İspanya ve sömürge öncesi New Mexico'dan olmak üzere iki örnek olay incelemesi, sır teknolojisinin farklı alanlarda çalışan çömlekçiler tarafından benimsenmesi ve uyarlanması için bir firsat sağlamıştır. Öte yandan, New Mexico'daki ev eşyası alanındaki cam eşyalarının üretimi, muhtemelen farklı cam hammaddelerinin kullanımına ve/veya orijinal üretim alanının dışında yer alan çömlekçiler tarafından yapılan bir tarifle ilgili bilgi eksikliğine bağlı olarak, sır pigment görünüşünde bir değissiklik sergilemektedir.

Dolayısıyla, petrografi, camın teknolojik bilgisinin edinildiği ve fikir yayılımı olarak değiştirildiği yollar hakkında değerli bilgiler sağlayabilir. Misır sır süsü örnekleri, dekorasyonu, petrografik grubu, sır özellikleri ve tahmini pişirim sıcaklıkları Tablo14'te incelenmiştir.

Bu çalışmada incelenen Mısır sır örnekleri ve ince kesitli mikro fotoğraflar Şekil 22'de verilmiştir. Tüm örnek görüntüleri teknenin iç kısmını göstermektedir. 


\begin{tabular}{|c|c|c|c|c|c|c|}
\hline Numune No & Süsleme & $\begin{array}{l}\text { Petrografik } \\
\text { Grup }\end{array}$ & $\begin{array}{l}\text { Sirdaki } \\
\text { Baloncuk }\end{array}$ & Sırdaki Kum & $\begin{array}{l}\text { Sırdaki Diğer } \\
\text { Bileşenler }\end{array}$ & $\begin{array}{l}\text { Pişirim } \\
\text { Sıcaklığı }\left({ }^{\circ} \mathrm{C}\right)\end{array}$ \\
\hline 22 & $\begin{array}{l}\text { Beyaz üzerine } \\
\text { mavi }\end{array}$ & Grup 1 (marl) & Nadir & Nadir & Kireç? & 850 \\
\hline 106 & $\begin{array}{l}\text { Beyaz üzerine } \\
\text { mavi }\end{array}$ & Grup 1 (marl) & Nadir & Nadir & Kireç? & 850 \\
\hline 107 & Koyu beyaz & Grup 1 (marl) & Sik & Nadir & Kireç? & 850 \\
\hline 87 & $\begin{array}{l}\text { Mavi-yeşil ve } \\
\text { siyah }\end{array}$ & Grup 1 (marl) & Nadir & Nadir & Kireç? & 800 \\
\hline 90 & Mavi ve Siyah & Grup 1 (marl) & Nadir & Nadir & Kireç? (Nadir) & 800 \\
\hline 102 & $\begin{array}{l}\text { Mavi ve siyah, } \\
\text { camsı değil }\end{array}$ & $\begin{array}{l}\text { Grup } 1 \text { (kalkerli } \\
\text { kireç- nil) }\end{array}$ & Sik & Sik & Kireç? Cam? & 850 \\
\hline 66 & $\begin{array}{l}\text { Soluk } \\
\text { çizgiler }\end{array}$ & $\begin{array}{l}\text { Grup } 1 \text { (kalkerli } \\
\text { kireç-nil) }\end{array}$ & Çok nadir & Yok & $\begin{array}{l}\text { Pigment } \\
\text { kristalleri? }\end{array}$ & 850 \\
\hline 63 & $\begin{array}{l}\text { Mavi } \\
\text { püskürtülmüş } \\
\text { siyah çizgili }\end{array}$ & $\begin{array}{l}\text { Grup 1 (kalkerli } \\
\text { kireç-nil) }\end{array}$ & Çok nadir & Yok & Yok & 800 \\
\hline 118 & $\begin{array}{l}\text { Mavi ve siyah } \\
\text { çizgili }\end{array}$ & $\begin{array}{l}\text { Grup } 1 \text { (kalkerli } \\
\text { kireç-nil) }\end{array}$ & Nadir & Nadir & Yok & 800 \\
\hline 141 & $\begin{array}{l}\text { Sarı, yeşil ve } \\
\text { kahverengi sır }\end{array}$ & $\begin{array}{l}\text { Grup } 2 \text {, Aswan } \\
\text { kili }\end{array}$ & Çok nadir & Yok & Yok & 800 \\
\hline 195 & Koyu yeşil & $\begin{array}{l}\text { Grup 2, Aswan } \\
\text { kili }\end{array}$ & Yok & Yok & Yok & 800 \\
\hline 38 & Var 1 Yeşil sır & $\begin{array}{l}\text { Grup 2, Aswan } \\
\text { kili }\end{array}$ & Yok & Yok & Yok & 800 \\
\hline 5931 & $\begin{array}{l}\text { Sarı, yeşil ve } \\
\text { siyah sır }\end{array}$ & $\begin{array}{l}\text { Grup 2, Aswan } \\
\text { kili }\end{array}$ & Yok & Yok & Yok & 800 \\
\hline 13 & $\begin{array}{l}\text { Beyaz üzerine } \\
\text { mavi }\end{array}$ & $\begin{array}{l}\text { Grup } 3, \quad \text { taş } \\
\text { pastası }\end{array}$ & Nadir & Nadir & Yok & $>850$ \\
\hline 157 & Zeytin yeşili & $\begin{array}{lll}\text { Grup } & 3, \quad \text { taş } \\
\text { pastası } & \end{array}$ & Nadir & Yok & Pigment kristali & $>850$ \\
\hline 176 & Açık camsı yeşil & $\begin{array}{l}\text { Grup } 3, \quad \text { taş } \\
\text { pastası }\end{array}$ & Nadir & Sik & Yok & $>850$ \\
\hline 62 & $\begin{array}{l}\text { FFS polikrom } \\
\text { (beyaz üzerine } \\
\text { mavi püskürtme) }\end{array}$ & $\begin{array}{l}\text { Grup } 3, \quad \text { taş } \\
\text { pastası }\end{array}$ & Nadir & Yok & Yok & $>850$ \\
\hline 14 & FFS yeşil & $\begin{array}{l}\text { Grup } 3, \quad \text { taş } \\
\text { pastası }\end{array}$ & Çok nadir & Yok & Yok & $>850$ \\
\hline 36 & FFS mavi & $\begin{array}{l}\text { Grup } 3, \quad \text { taş } \\
\text { pastası }\end{array}$ & Sik & Sik & Yok & $<850$ \\
\hline 37 & FFS sarı & $\begin{array}{l}\text { Grup } 3, \quad \text { taş } \\
\text { pastası }\end{array}$ & Nadir & Yok & Yok & $<850$ \\
\hline 46 & Var 2 mavi-yeşil & $\begin{array}{l}\text { Grup } 3, \quad \text { taş } \\
\text { pastası }\end{array}$ & Nadir & Nadir & Yok & $>1000$ \\
\hline 67 & $\begin{array}{l}\text { Mavi } \\
\text { püskütrmeli } \\
\text { siyah çizgili }\end{array}$ & $\begin{array}{l}\text { Grup } 3, \quad \text { taş } \\
\text { pastası }\end{array}$ & Nadir & Yok & Cams1 & $>850$ \\
\hline
\end{tabular}

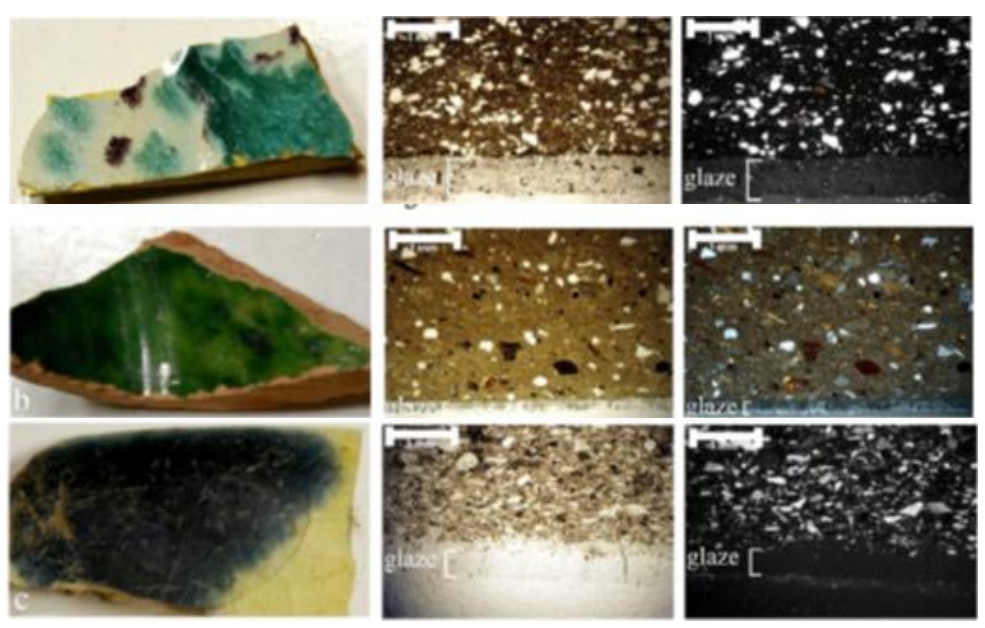

Şekil 22. (a) Mısır sırlı örnekler ve ince kesitli mikro fotoğraflar kalkerli kil, (b) Aswan kili, (c) FFS polikrom taş pastası [47]. 
Bir diğer çalışmaya ait Rio Grande sırlı ürün örnekleri ve ince kesit mikro fotoğrafları Şekil 23’te gösterilmiştir. Tüm örnek görüntüleri eşyanın iç kısmına aittir. Büyütme 40×'dir.

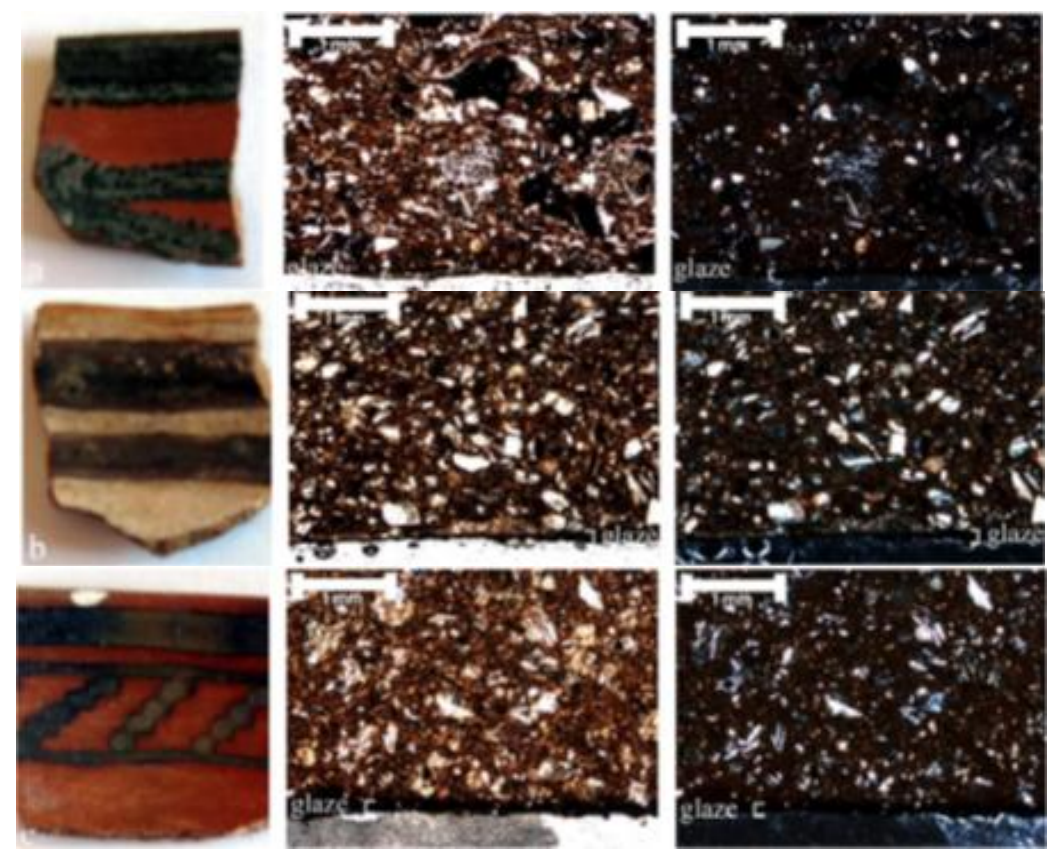

Şekil 23. Rio Grande sırlı ürün örnekleri ve ince kesit mikro fotoğrafları, (a) siyah camsı sır, (b) siyah camsı olmayan sir, (c) siyah yarı camsı sir [47].

$\mathrm{Bu}$ çalışmada, çok farklı kültürlerden gelen iki seramik topluluğu incelenmiştir. Her iki çalışmada da zaman içinde sır eşyalarının üretimindeki değişikliklere işaret eden bazı kronolojik gelişmeler vardır. Misır sır süsü analizleri, muhtemelen 9. ve 15. yüzyıllardan kalma bir zaman diliminde, belki de daha sonra, Rio Grande sırlı ürün ise 14-17. yüzyılları arasındadır. Ortak tema, farklı alanlardaki sosyo-politik sistemlerle iki alanda meydana gelen sırların üretimi konusunda teknolojik bilginin aktarımıdır. Mısır'da, doğrudan ve dolaylı bilgi aktarımının bir kombinasyonu muhtemeldir ve çömlek üretimi, geniş bir dağıtım için kontrollü, endüstriyel ortamda gerçekleşmiştir. New Mexico'da, Rio Grande sırlı ürün üretimi, muhtemelen daha az idari kontrole sahip bir hane veya köy düzeyinde olmasına rağmen, uzman üreticiler bağlamında yapılmıştır. Galisteo Pueblos ve Cerillos madenlerine dayanan Rio Grande boyunca geniş çaplı değişim ağlarına katılım, teknolojik bilginin dağıtılmasında anahtar faktörlerden biri olabilir. Katkıda bulunan bir faktör, İspanyol işgücü piyasasının talepleri ve İspanyol misyonunun bilgi ve hammaddelere erişimi kısıtlayan demografik etkileri olmuştur. Özetle, teknolojik bilginin aktarımı, uyarlanması ve rekreasyon, şaşırtıcı bir şekilde, sosyo-politik bağlam ve bölgedeki hammaddelerden etkilenmektedir. $\mathrm{Bu}$, hem teknolojik bilgi aktarımına hem de seramik ekolojisi şeklinde adlandırılabilecek bir çevresel belirleyici ve sosyal gömülü bakış açısı sağlar.

Taş işçiliği için kil esaslı bir sistemde altın-bronz metalik sırların geliştirilmesi Pekkan vd. tarafından çalışılmıştır [48]. Kırmızı kil, kaolen, kuvars, $\mathrm{MnO}, \mathrm{CuO}$ ve CoO'dan oluşan üç eksenli bir sır sistemi, taş işçiliği için altın-bronz ham metalik sırlar üretmek üzere sistematik biçimde geliştirilmiştir. İlk olarak, geliştirilen sistemdeki tüm sırlı numuneler, $1160{ }^{\circ} \mathrm{C}$ 'de elektrik 1sıtmalı bir firında ısıl işleme tabi tutulmuştur. Daha sonra, seçilen başarılı altın bronz metalik sırlar 3-D taş dokular formuna uygulanmış ve aynı koşullarda sinterlenmiştir. Sırların mikro-yapısal karakterizasyonu, SEM ve EDX analizleri ile yapılmıştır. Sırların kimyasal bileşiminin rengi doğrudan etkilediği ve CuO'nun altın-bronz etkisine ulaşmak için MnO'dan daha önemli olduğu gözlenmiştir. İncelenen üç eksenli sır sistemi Şekil 24’te verilmiştir. 


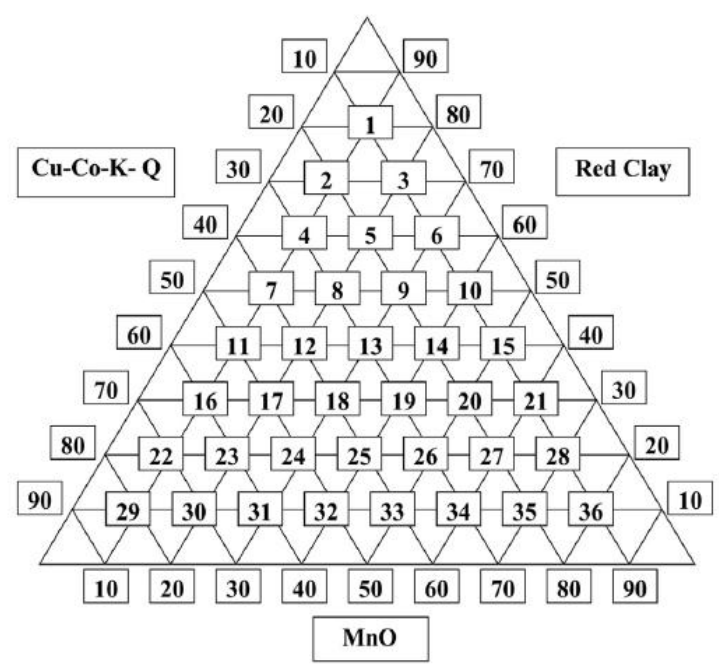

Şekil 24. Üç eksenli sır sistemi (Cu: CuO, Co: CoO, K: Kaolen, Q: Kuvars) [48].

Hammadde miktarlarının doğrudan metalik görünümü ve yüzey dokusunu etkilediği bulunmuş, MnO'in artan miktarlarının daha parlak metalik yüzeylere yol açtığı görülmüştür.

Tablo15. Sirların hammadde oranları [48]

\begin{tabular}{|c|c|c|c|c|c|c|}
\hline \multirow[t]{2}{*}{ Reçete No } & \multirow[t]{2}{*}{ Kırmızı Kil } & \multirow[t]{2}{*}{ MnO } & \multicolumn{2}{|c|}{ Cu-Co-K-Q } & \multirow[b]{2}{*}{ Kaolen } & \multirow[b]{2}{*}{ Kuvars } \\
\hline & & & $\mathrm{CuO}$ & $\mathrm{CoO}$ & & \\
\hline 1 & 80 & 10 & 2,5 & 2,5 & 2,5 & 2,5 \\
\hline 2 & 70 & 10 & 5 & 5 & 5 & 5 \\
\hline 3 & 70 & 20 & 2,5 & 2,5 & 2,5 & 2,5 \\
\hline 4 & 60 & 10 & 7,5 & 7,5 & 7,5 & 7,5 \\
\hline 5 & 60 & 20 & 5 & 5 & 5 & 5 \\
\hline 6 & 60 & 30 & 2,5 & 2,5 & 2,5 & 2,5 \\
\hline 7 & 50 & 10 & 10 & 10 & 10 & 10 \\
\hline 8 & 50 & 20 & 7,5 & 7,5 & 7,5 & 7,5 \\
\hline 9 & 50 & 30 & 5 & 5 & 5 & 5 \\
\hline 10 & 50 & 40 & 2,5 & 2,5 & 2,5 & 2,5 \\
\hline 11 & 40 & 10 & 12,5 & 12,5 & 12,5 & 12,5 \\
\hline 12 & 40 & 20 & 10 & 10 & 10 & 10 \\
\hline 13 & 40 & 30 & 7,5 & 7,5 & 7,5 & 7,5 \\
\hline 14 & 40 & 40 & 5 & 5 & 5 & 5 \\
\hline 15 & 40 & 50 & 2,5 & 2,5 & 2,5 & 2,5 \\
\hline 16 & 30 & 10 & 15 & 15 & 15 & 15 \\
\hline 17 & 30 & 20 & 12,5 & 12,5 & 12,5 & 12,5 \\
\hline 18 & 30 & 30 & 10 & 10 & 10 & 10 \\
\hline 19 & 30 & 40 & 7,5 & 7,5 & 7,5 & 7,5 \\
\hline 20 & 30 & 50 & 5 & 5 & 5 & 5 \\
\hline 21 & 30 & 60 & 2,5 & 2,5 & 2,5 & 2,5 \\
\hline 22 & 20 & 10 & 17,5 & 17,5 & 17,5 & 17,5 \\
\hline 23 & 20 & 20 & 15 & 15 & 15 & 15 \\
\hline 24 & 20 & 30 & 12,5 & 12,5 & 12,5 & 12,5 \\
\hline 25 & 20 & 40 & 10 & 10 & 10 & 10 \\
\hline 26 & 20 & 50 & 7,5 & 7,5 & 7,5 & 7,5 \\
\hline 27 & 20 & 60 & 5 & 5 & 5 & 5 \\
\hline 28 & 20 & 70 & 2,5 & 2,5 & 2,5 & 2,5 \\
\hline 29 & 10 & 10 & 20 & 20 & 20 & 20 \\
\hline 30 & 10 & 20 & 17,5 & 17,5 & 17,5 & 17,5 \\
\hline 31 & 10 & 30 & 15 & 15 & 15 & 15 \\
\hline 32 & 10 & 40 & 12,5 & 12,5 & 12,5 & 12,5 \\
\hline 33 & 10 & 50 & 10 & 10 & 10 & 10 \\
\hline 34 & 10 & 60 & 7,5 & 7,5 & 7,5 & 7,5 \\
\hline 35 & 10 & 70 & 5 & 5 & 5 & 5 \\
\hline 36 & 10 & 80 & 2,5 & 2,5 & 2,5 & 2,5 \\
\hline
\end{tabular}


Bununla birlikte $\mathrm{CuO}$ miktarı altın-bronz rengini üretmek için MnO'dan daha fazla belirleyicidir. $\mathrm{Cu}$ ve $\mathrm{Mn}$ genellikle altın-bronz metalik sır yüzeylerinde tespit edilir, ancak kristallerin şekli kimyasal sır bileşimlerine göre değişmektedir.

İran'ın güneydoğusundaki karbonat altlıklar üzerinde silis açısından zengin kaplama Aftabi vd. tarafından rapor edilmiştir [49]. Bu çalışmada jeo-kimyasal işaretler ve silisli karbonat altılıklar üzerinde geliştirilen, silis bakımından zengin kaplamaların oluşumu hakkında birkaç veri bulunmaktadır. Güneydoğu-İran'daki Maran-e-Galu bölgesindeki kaya kaplamaları dört katmandan oluşmaktadır; daha düşük kalın bir tabaka $(1 \mathrm{~mm})$ silika, daha düşük ince Fe-Mn oksit filmi, üst kalın $(1 \mathrm{~mm})$ silis açısından zengin tabaka ve üst Fe-Mn oksit filmi. XRF ve ICP-MS ile EDS, XRD ve yığın kaplama jeokimyası verileri, 1-3 mm kalınlığında silis bakımından zengin kaplamaların silisli karbonat altlık üzerinde bir opal bileşimin silika sırı olarak oluştuğunu göstermektedir. Orta İran'ın Maran-e-Galu bölgesindeki karbonat baskın alt tabaka üzerinde 1-3 mm kalınlığında silis açısından zengin bir kaya kaplamasının oluşumunu anlatmaktadır. Kaplamalar, çok ince Fe-Mn oksit filmleri ile kaplanmış kalın silis açısından zengin tabakalardan meydana gelmektedir. Ba ve Sr'nın yüksek değerleri silika açısından zengin kaplamaların tortul kökenine işaret eder, ancak kırmızı-kahverengi renge herhangi bir benzerlik göstermez.

Barok sunaklarından lüster camlı yaldız ve gümüşlemenin mikro-analitik çalışması Salvado vd. tarafından yapılmıştır [50]. Parlaklık ve gümüş kaplama üzerine renkli yarı saydam sırların uygulanmasını içeren bir teknik olan lüster, Barok dönemindeki sunak parçalarını zenginleştirmek ve süslemek için yaygın biçimde kullanılmıştır. Süslemeler, çeşitli renkteki sırları, metalik yapraklar ve alçı zemin üzerine uygulanan balçı içeren mikro-metrik çok katmanlı bir yapıdan oluşur. Tortosa (Katalonya) katedralinden en eski tarih olan 1671 ve en yeni 1775 tarihli Barok sunakların koleksiyonu, kullanılan malzemeler ve dönem boyunca başvurulan tekniklerin

Tablo 16. Malzeme özellikleri [50]

\begin{tabular}{|c|c|c|c|c|}
\hline Altar Panosu & Numune No & Sur & Metal & Çamur \\
\hline \multirow[t]{2}{*}{ All souls } & 1 & Turuncu & Gümüş & Kırmızı \\
\hline & 1 & Kehribar & & \\
\hline \multirow{4}{*}{ Saint Joachim } & 2 & Kehribar & Altın & \\
\hline & 1 & Turuncu & Gümüş & \\
\hline & 3 & Mavi & & \\
\hline & 1 & Kirmız1 & & \\
\hline Saint Joachim & 2 & - & Gümüş & Kirmız1-Mor \\
\hline \multirow[t]{2}{*}{ Altar Frontal } & 1 & Sar1 & & \\
\hline & 1 & - & Altın & \\
\hline \multirow[t]{7}{*}{ Saint Rufus } & 2 & - & Altın & Kirmız1-Mor \\
\hline & 1 & Kehribar & & \\
\hline & 1 & K1rm1z1 & & \\
\hline & 1 & Yeşil & Gümüş & \\
\hline & 3 & kırmızı & & \\
\hline & 1 & - & & \\
\hline & 1 & Kehribar & & \\
\hline \multirow[t]{6}{*}{ Our lady of the Rosary } & 1 & Kehribar & & \\
\hline & 1 & Kırmız1 & & \\
\hline & 1 & Yeşil & & \\
\hline & 1 & Mavi & & \\
\hline & 1 & Yeşil & Altın & \\
\hline & 1 & Kirm1z1 & & \\
\hline
\end{tabular}

Şekil 25'te söz konusu çalışma için alınan örneklerden gümüş yaprak korozyonuna ait SEM ve XRD sonuçları verilmiştir. 

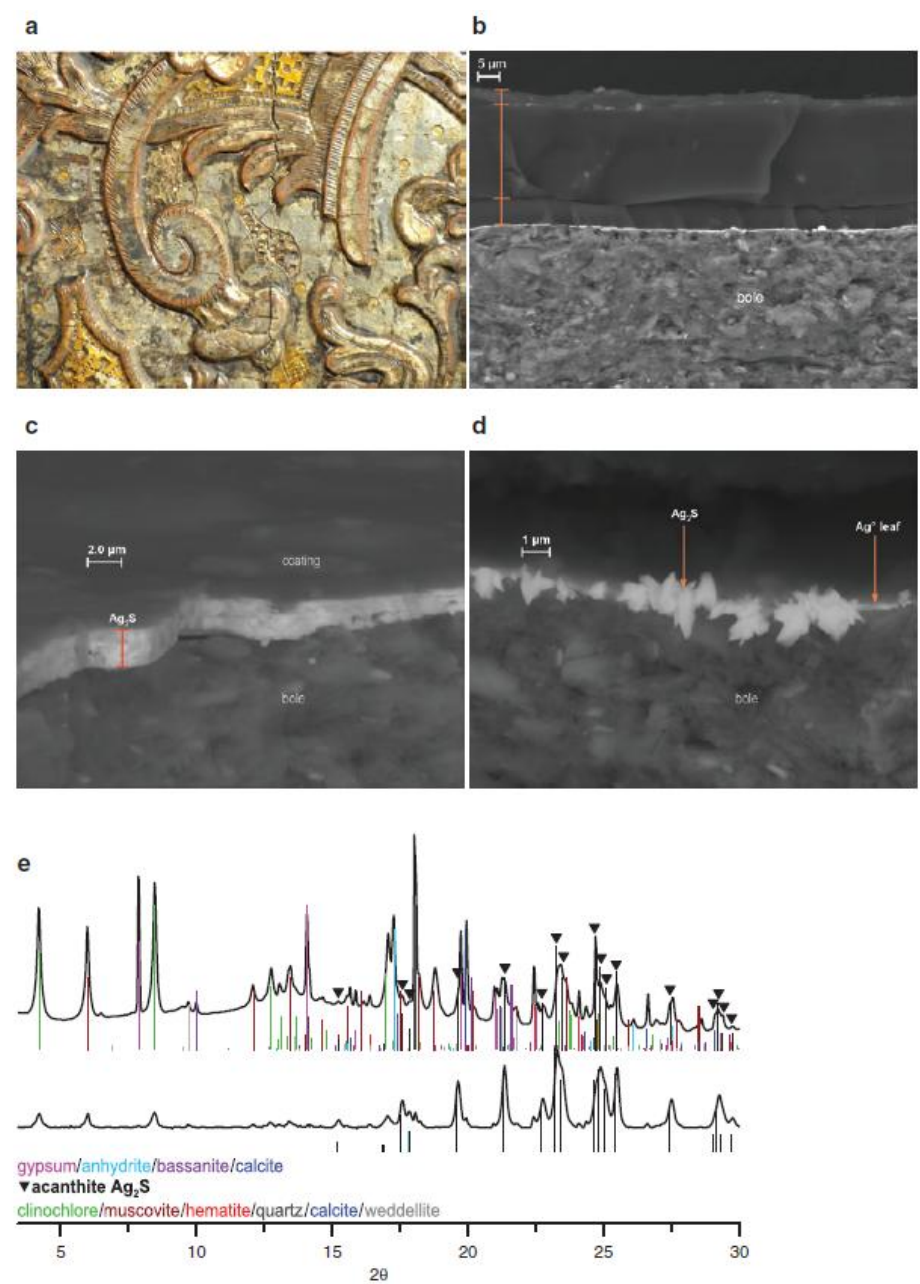

Şekil 25. Bu çalışmada alınan örneklerin SEM ve XRD sonuçları [50].

mükemmel örnekleridir. Kullanılan malzemelerin köken ve doğası ile ilgili tarihsel ve korunan bakış açıları ile ilgili bilgiler, lüsterlerin ortaya çıkması ve bunların reaktivitesi ve yaşlanması tartışılmaktadır. Tortosa katedralinde 30 adet örnek alınmıştır. Tablo 16'da bu malzemelerin özellikleri verilmiştir.

Şekil 26'da ise gümüşleme üzerinde renkli saydam camlar ve onlara ait analiz sonuçları gösterilmiştir.

17. yüzyılın son çeyreğinden ve Tortosa Katedralinden 18. yüzyıla uzanan bir dizi Barok sunaktan parlaklık ve gümüş parlaklığı incelenmiştir. Sınırlı nüfuz edilebilirlik düşünülmüş ve bunun için sunaklardan seçilmiş mikron boyutunda örnekler seçilmiştir. Örneklerin orijinal tabakalı mikroyapısını değiştirmeden analizi mümkün kılan mikro-analitik teknikler kümesinin bir araya getirilmesi stratejisi, kullanılan orijinal malzemeler, bunların arasındaki ve farklı katmanlar arasındaki tepkimeler (metalik sırlar) hakkında bilgi edinilmesini sağlamaktadır. 

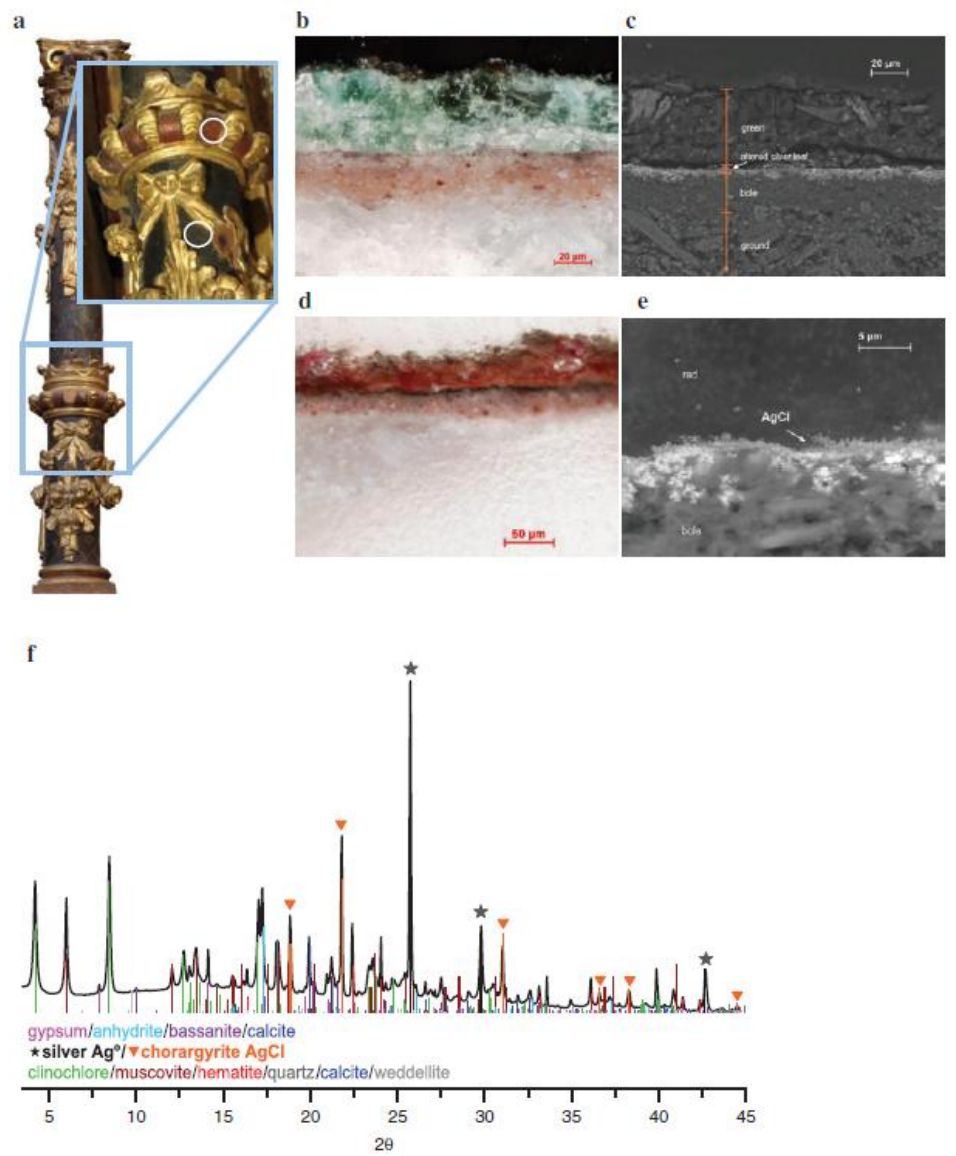

Şekil 26. Gümüşleme üzerinde renkli saydam camlar ve analiz sonuçları [50].

\section{Sonuç}

Estetik görünümlerinden dolayı albenisi çok yüksek sırlardan biri olan lüster grubu yüzyıllardan beri insanoğlunun yaşam kalitesine katkıda bulunmaktadır. Gerek sanatsal gerekse işlevsel anlamda günümüzün çok tercih edilen sırlarındandırlar. Hem sanatsal dokunuşlar hem modern yaklaşımlar hem de arkeolojik çalışmalarıyla sanat ve bilim insanlarının önem verdiği konular arasında da yer almaya devam edecektir.

\section{Kaynakça}

[1] Kreibig M., Vollmer U., "Optical properties of metal clusters”, 1995.

[2] Pradell T., Molera J., Smith A. D. and Tite M. S., "The invention of lustre: Iraq $9^{\text {th }}$ and $10^{\text {th }}$ centuries AD”, J. Archaeol. Sci., 2008, 35, 5:1201-1215.

[3] Carboni S., "Glass from Islamic lands, Thames \& Hudson in association with the al-Sabah Collection, Dar al-Athar al-Islamiyyah", Kuwait National Museum. London, UK, 2001.

[4] Caiger Smith A. C., "Lustre pottery", New Amsterdam Books, New York, 1991.

[5] Pradell T., Molera J., Roque J., Vendrell-Saz M., Smith A. D., Pantos E. and Crespo D., "Ionic-exchange mechanism in the formation of medieval luster decorations," J. Am. Ceram. Soc., 2005, 88, 5:1281-1289.

[6] Climent-Font A., "Commentary: Luster ceramics: A $9^{\text {th }}$ century AD nanotechnology", J. Nanophotonics, 2012, 6, 1: 060303.

[7] Mason R. B., "Shine like the sun. Lustre-painted and associated pottery from the Medieval Middle East, Bibliotheca Iranica: Islamic Art and Architecture Series", 12. Mazda Publishers, Inc., Costa Mesa Canada. Molera, 2004. 
[8] Martinon-Torres T. R. M., Ed., "Archaeology, history and science", Left Coast Press, 2008.

[9] https://www.metmuseum.org/art/collection/search/450933 (Erişim Tarihi: 07.07.2018) .

[10] https://www.dia.org/art/collection/object/luster-painted-armorial-plate-49210 (Erişim Tarihi: 07.07.2018).

[11] http://www.fitzmuseum.cam.ac.uk/research/lustreware (Erişim Tarihi: 07.07.2018).

[12] http://www.discoverislamicart.org/ (Erişim Tarihi: 07.07.2018).

[13] https://ah.atec.io/tag/luster-painting/ (Erişim Tarihi: 07.07.2018).

[14] https://depts.washington.edu/silkroad/museums/mik/miklaterislam.html (Erişim Tarihi: 07.07.2018).

[15] https://www.brooklynmuseum.org/opencollection/objects/125958 (Erişim Tarihi: 07.07.2018).

[16] http://www.masterart.com/ (Erişim Tarihi: 07.07.2018).

[17] http://jameelcentre.ashmolean.org/collection/4/837/861 (Erişim Tarihi: 07.07.2018) .

[18] https://artsandculture.google.com/asset/dish-design-of-flower-in-luster-paint-hispanomoresque/FQHTEOWHcKouLg (Erişim Tarihi: 07.07.2018) .

[19] https://artsandculture.google.com/asset/bowl-design-of-a-rabbit-in-luster-paint-hispanomoresque/2gHVK0dx71el0A (Erişim Tarihi: 07.07.2018).

[20] Italian Maiolica catalogue of the collections The J. Paul Getty Museum (Erişim Tarihi: 07.07.2018).

[21] http://love2fly.iberia.com/2014/05/talavera-pottery-spain-mexico/ (Erişim Tarihi: 07.07.2018).

[22] http://www.clevelandart.org/art/ (Erişim Tarihi: 07.07.2018).

[23] http://www.anaviangallery.com/servlet/q.QDisplayItemDetail?in=5736 (Erişim Tarihi: 07.07.2018).

[24] http://www.artic.edu/aic/collections/artwork/25376? search_no=9\&index=17 (Erişim Tarihi: 07.07.2018).

[25] "https://global.britannica.com/media/full/295642/36387 (Erişim Tarihi: 07.07.2018).

[25] Pérez-Arantegui J., Molera J., Larrea A., T. Pradell T and Vendrell-Saz M., "Luster pottery from the thirteenth century to the sixteenth century: A nanostructured thin metallic film", J. Amrican Ceram. Soc., 2001, 84, 2: 442-446.

[27] Borgia I., Brunetti B., Mariani I., Sgamellotti A., Cariati F., Fermo P., Mellini, M., Viti C. and Padeletti G., "Heterogeneous distribution of metal nanocrystals in glazes of historical pottery", Appl. Surf. Sci., 2002, 185, 3-4: 206-216.

[28] Padovani S., Sada C., Mazzoldi, P., Brunetti B., Giulivi A., D’Acapito F. and Battaglin G., "Copper in glazes of Renaissance luster pottery: Nanoparticles, ions, and local environment", J. Appl. Phys., 2003, 93, 12: 10058-10063.

[29] Fredrickx P., Hélary D., Schryvers D. and Darque-Ceretti E., "A TEM study of nanoparticles in lustre glazes", Appl. Phys. A Mater. Sci. Process, 2004, 79, 2: 283-288.

[30] Pradell T., Molera J., Vendrell M., Pérez-Arantegui J., Pantos E., Roberts M. and DiMichiel M., "Role of cinnabar in luster production", J. Am. Ceram. Soc., 2004, 87, 6: 1018-1023.

[31] Darque-Ceretti E., Helary D., Bouquillon A. and Aucouturier M., "Gold like lustre: Nanometric surface treatment for decoration of glazed ceramics in ancient Islam, Moresque Spain and Renaissance Italy", Surf. Eng., 2005, 21, 5-6: 352-358.

[32] Pradell T. Molera J., Bayés C. and Roura P., "Luster decoration of ceramics: Mechanisms of metallic luster formation”, Appl. Phys. A Mater. Sci. Process, 2006, 83, 2: 203-208.

[33] del Rio, A. P., Castaing J. and Aucouturier M., "Metallic nano-particles in lustre glazed ceramics from the $15^{\text {th }}$ century in Seville studied by PIXE and RBS", Nucl. Instruments Methods Phys. Res. Sect. B Beam Interact. with Mater. Atoms, 2006, 249, 1-2 SPEC. ISS.: 596-600.

[34] Roqué J., Molera J., Sciau P., Pantos E. and Vendrell-Saz M., "Copper and silver 
nanocrystals in lustre lead glazes: Development and optical properties”, J. Eur. Ceram. Soc., 2006, 26, 16: 3813-3824.

[35] Molera J., Bayés C., Roura P., Crespo D. and Pradell T., "Key parameters in the production of medieval luster colors and shines", J. Am. Ceram. Soc., 2007, 90, 7: 2245-2254.

[36] Roqué J., Molera J., Pérez-Arantegui J., Calabuig C., Portillo J. and Vendrell-Saz M., "Lustre colour and shine from the Olleries Xiques workshop in Paterna (Spain), $13^{\text {th }}$ century ad: Nanostructure, chemical composition and annealing conditions", Archaeometry, 2007, 49, 3: 511-528.

[37] Pradell T., Climent-Font A., Molera J., Zucchiatti A., Ynsa M. D., Roura P. and Crespo D., "Metallic and nonmetallic shine in luster: An elastic ion backscattering study", J. Appl. Phys., 2007, 101: 10.

[38] Pradell T., Molera J., Smith A. D. and Tite M. S., "Early Islamic lustre from Egypt, Syria and Iran $\left(10^{\text {th }}\right.$ to $13^{\text {th }}$ century AD)", J. Archaeol. Sci., 2008, 35, 9: 2649-2662.

[39] Pradell T., Molera J., Smith A. D., Climent-Font A. and Tite M. S., "Technology of Islamic lustre", J. Cult. Herit., 2008, 9, SUPPL.: e123-e128.

[40] Siligardi C., Montecchi M., Montorsi M. and Pasquali L., "Ceria-containing frit for luster in modern ceramic glaze”, J. Am. Ceram. Soc., 2010, 93, 9: 2545-2550.

[41] Gutierrez P. C., Pradell T., Molera J., Smith A. D., Climent-Font A. and Tite M. S., "Color and golden shine of silver Islamic luster", J. Am. Ceram. Soc., 2010, 93, 8: 2320-2328.

[42] Mestre S., Chiva C., Palacios M. D. and Amorós J. L., "Development of a yellow ceramic pigment based on silver nanoparticles", J. Eur. Ceram. Soc., 2012, 32, 11: 2825-2830.

[43] Gualtieri A. F., Canovi L., Viani A., Bertocchi P., Corradini C., Gualtieri M. L., Gazzadi G. C., Zapparoli M. and Berthier S., "Mechanism of lustre formation in scheelite-based glazes", J. Eur. Ceram. Soc., 2013, 33, 11: 2055-2064.

[44] Molina G., Tite M. S., Molera J., Climent-Font A. and Pradell T., "Technology of production of polychrome lustre", J. Eur. Ceram. Soc., 2014, 34, 10: 2563-2574.

[45] Razavi F., Rashidi M. and Mahdi H., "Production of luster glaze on opal tableware using Zarinfam technique and characterization of its structure and color", Appl. Phys. A, 2016, 122, 5: $1-8$.

[46] Sarıüzel M., Öztürk Y. and Günay E., "Studying the effect of different glaze compositions on the formation and properties of silver and copper nanoparticles in lustre decoration", Journal of the Australian Ceramic Society, April 2017, 53, 1: 21-28.

[47] Ownby M. F., Giomi E. and Williams G., "Glazed ware from here and there: Petrographic analysis of the technological transfer of glazing knowledge", J. Archaeol. Sci. Reports, 2017, 16: 616-626.

[48] Pekkan K., Başkırkan H. and Çakı M," "Development of gold-bronze metallic glazes in a clay-based system for stoneware bodies", Ceram. Int., 2018, 44, 5: 4789-4794.

[49] Aftabi A. and Atapour H. "A new record of silica-rich coating on carbonate substrates in southeast-central Iran: Constraints on geochemical signatures", Sedimentary Geology, 2018, 372: 64-74.

[50] Salvadó N., Butí S., Clemente C., Beltran V., Cinque G., Juanhuix J. and Pradell T., "Microanalytical study of luster glazed gilding and silvering from Baroque altarpieces", Pure Appl Chem., 2017, 90, 3: 477-492. 